\section{ANALES DEL INSTITUTO DE INVESTIGACIONES ESTETICAS}

Anales del Instituto de Investigaciones

\section{Estéticas}

ISSN: 0185-1276

iieanales@gmail.com

Instituto de Investigaciones Estéticas

México

CUADRIELLO, JAIME

El padre Clavijero y la lengua de san Juan Nepomuceno

Anales del Instituto de Investigaciones Estéticas, vol. XXXIII, núm. 99, 2011, pp. 137-179

Instituto de Investigaciones Estéticas

Distrito Federal, México

Disponible en: http://www.redalyc.org/articulo.oa?id=36928271006

- Cómo citar el artículo

- Número completo

- Más información del artículo

- Página de la revista en redalyc.org

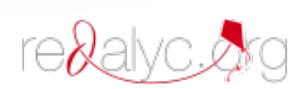

Sistema de Información Científica

Red de Revistas Científicas de América Latina, el Caribe, España y Portugal Proyecto académico sin fines de lucro, desarrollado bajo la iniciativa de acceso abierto 


\author{
JAIME CUADRIELLO \\ INSTITUTO DE INVESTIGACIONES ESTÉTICAS, UNAM
}

\title{
El padre Clavijero y la lengua de san Juan Nepomuceno
}

Pero no, no se imagine que haya de ser eterna nuestra infamia entre los hombres. Dios tendrá cuidado de restablecer nuestro honor, aunque no hagamos de nuestra parte más diligencia que tolerar con resignación los golpes de la calumnia. Esto mismo ha practicado Dios con todos los santos convirtiéndoles la infamia en honor, la ignominia en celebridad y la confusión en gloria. Y lo mismo debemos creer que hará con nosotros, si llevamos con paciencia nuestra deshonra. Está a la puerta el juez que a todos nos ha de juzgar.

Francisco Xavier Clavijero, 1773

\section{A Juana Gutiérrez, in memoriam ${ }^{\mathrm{I}}$}

Na de las facetas menos Conocidas de la vida del padre Francisco Xavier Clavijero fue haberse desempeñado como ministro confesor, acorde con las características de la disciplina jesuítica: la obediencia

I. Traigo este tema como artículo por una simple y sencilla razón afectiva: es una sentida dedicatoria para Juana Gutiérrez Haces (1948-2007). Tal como manifestó a varios de sus compañeros del Instituto de Investigaciones Estéticas de la Universidad Nacional Autónoma de México, era Juana "Nepomucena" de nombre de pila, que le venía de muy atrás por una sostenida devoción familiar. Así también porque fue una estudiosa apasionada de la labor intelectual de los jesuitas del siglo XVIII (en especial de la obra anticuaria del padre Pedro José Márquez). Y, desde luego, porque así he querido honrar su aguerrido espíritu justiciero, que todos los del gremio le conocimos (y temimos) y con el cual, de manera admonitoria y correctiva, ilustraba nuestro desempeño académico. 
apostólica, las peculiaridades de la vida activa y las prácticas de la religiosidad moderna. Al menos a esto se dedicó varios años entre lo más granado - y lo no tanto- de los fieles de la Puebla de los Ángeles. Incluso confesando en náhuatl a sus indios educandos de los colegios para nobles de San Gregorio de México y San Javier de Puebla y con ello regresándoles el favor de haber sido enseñado, en esa lengua, por los mismos indios colegiales. Apenas ordenado sacerdote, Clavijero entendió que su deseo era "la salvación de las almas" y para admiración de muchos "se mostró incansable en el confesionario, no excusándose jamás, por sus quehaceres, de la asistencia". De tal suerte era congruente en todos "los ministerios con los prójimos en [el] confesionario", y así se le veía transitando entre "moribundos, cárceles y hospitales, en que haciendo gran fruto en las almas, gozaba [de] gran consolación de espíritu". ${ }^{2}$ Con estas sentidas palabras, lo afirmaba su biógrafo el padre Félix de Sebastián, no sin un dejo propio del género hagiográfico $y$, sin duda, la melancolía que le acarreaba la tragedia del exilio. Al cabo sacerdote, dimensionando toda su trayectoria humana, literaria y cristiana, Clavijero todavía se muestra como un ser por demás complejo y atractivo, dada la reciedumbre de un carácter de excepción, patente en su personalidad culta e ilustrada y su prosa elegante y reservada y, como aquí veremos, en medio del drama de un itinerario intelectual casi siempre adverso o nadando a contracorriente de los prejuicios y esquemas de su tiempo.

Era previsible que en aquella sociedad a un confesor se le granjease el respeto y el aprecio, por el ascendiente moral que adquiría entre familias y corporaciones, más aún en alguien de las prendas intelectuales del que sería autor de la Historia antigua de México. De hecho, uno de sus primeros sermones que fueron "muy alabados por el público culto" fue precisamente aquél enderezado en "contra de los errores de algunos que, sin la ciencia sagrada requerida, osaban oír confesiones". 3 Sin embargo, el ejercicio de este ministerio también atraía riesgos y sinsabores por la discrecionalidad y susceptibilidad que se ponía entonces en juego y el poder que adquiría el ministro en la toma de decisiones del penitente (no por nada el obispo Palafox se había empeñado en que los jesuitas mostraran sus credenciales para predicar y confesar, sin duda como una forma de controlar sus redes entre los laicos). La conservación del sigilo y

2. Elías Trabulse, Francisco Xavier Clavigero [incluye la publicación de la biografía del padre Félix de Sebastián], México, Novus Orbis, 1987, p. 4I.

3. Juan Luis Maneiro, Vidas de algunos mexicanos ilustres, México, Universidad Nacional Autónoma de México-Instituto de Investigaciones Filológicas, I988, p. 450. 

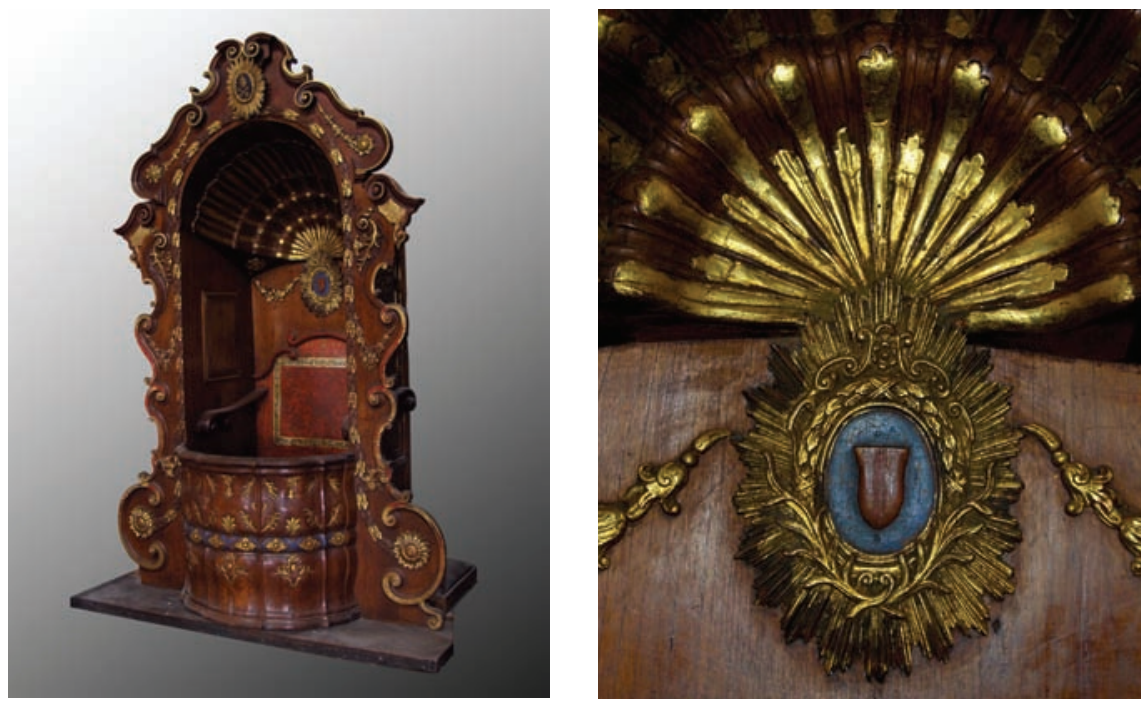

Ia) Anónimo, Confesionario, segunda mitad del siglo xvinI, talla de madera policromada. parroquia del Pocito, Villa de Guadalupe. Foto: Eumelia Hernández. Conaculta-INAH-MÉx. "Reproducción autorizada por el Instituto Nacional de Antropología e Historia"; b) detalle.

la buena fama que debía acompañar a todo confesor eran aspectos fundamentales y delicados en el trato: era el referente más apreciado entre los suyos o bien podía entrar en conflictos indeseables, más aún si se relacionaba con personas de renombre, ya que estaba, a la vista de todos, el buen o mal desarrollo de esta práctica sacramental. En primer lugar, para evitar las murmuraciones o miradas escabrosas, el ministro tenía que predicar con el ejemplo y cuidarse del dicho: "no dar de qué hablar". La solicitación de favores a través del auricular del confesionario, ya fuera de índole sexual o de poder, era la práctica más condenada precisamente porque transgredía el secreto y la santidad de un sacramento fundamental para dirigir las conciencias (aunque hoy todo parezca un contrasentido) (fig. I).

Así, mientras Clavijero impartía esmeradamente la absolución al prójimo contrito y pecador, honrando la teoría y la práctica, moría en Puebla su hermano Manuel, un joven sacerdote secular muy amado por él y por muchos de sus allegados. Entonces le dedicó un sentido panegírico como homenaje póstumo, donde ponderaba sus virtudes y se servía de su vida ejemplar como 
mecanismo de imitación y edificación moral. ${ }^{4}$ Para el autor de las Memorias edificantes (título que dio a la pieza), esta ocasión no sólo era la oportunidad de ensayar sus dotes para la historia y el discurso, sino de ser consecuente con la verdad y el juicio crítico, no obstante su cercanía genética y emocional. En aquellas páginas no había contradicción entre sus prácticas morales y sus principios intelectuales: "No estorbaba el parentesco a la fe prestada por los lectores al escrito, porque eran públicos la virtud y bondad del biografiado y pública la honradez científica del biógrafo", afirmó, en su sentida semblanza, Juan Luis Maneiro. 5 En realidad, Clavijero contaba varios episodios de su infancia y revelaba la mansedumbre y la bondad, la mesura y el equilibrio con que su padre condujo a la familia y el carácter que tuvo que templar su madre, Isabel, para atemperar su ánimo colérico e iracundo. Estas virtudes se transmitieron a su hermano, que era un ejemplo vivo de la moderación y el recato, la austeridad y la tolerancia. Manuel se desempeñó como generoso albacea, toda vez que sus hermanos menores quedaron en la orfandad, y así, con la ausencia del renombre del padre y la pérdida de la posición que les había granjeado, los hermanos Clavijero también resintieron el menosprecio de algunos de sus parientes y conocidos.

Tan aplaudida resultó esta pieza moral que, siguiendo el consejo de criterios imparciales, se atrevió a publicarla (aunque no sabemos si con la debida aprobación de sus superiores). Sin embargo, "como la verdad desnuda suele acarrear dificultades a quien hace historia", entre aquellos poblanos no faltó alguien que se sintiera ofendido "y levantó una tempestad en un vaso de agua"; y nada menos era un individuo que se decía pariente del difunto, que, con saña y encono, emprendió una aviesa persecución que intentaba apagar la brillante pluma del joven escritor. A tan poderoso y enfebrecido acusador, dice Sebastián, "no hubo modo de sosegarlo con demostrarle que en nada se hablaba contra él, mas éste jamás se sosegó pretendiendo fuera castigado el sujeto". Se dirigió a los tribunales y pidió que la obra fuese recogida con el consecuente castigo, incluso a quien osara leerla o citarla. En suma, por atreverse a ejercer su "cris-

4. Francisco Xavier Clavijero, Memorias edificantes del Br. Manuel Joseph Clavijero, sacerdote del obispado de Puebla, recogidas por su hermano el P. Mariano Xavier Clavijero, de la Compañía de Jesús, México, Imprenta de Zúniga y Ontiveros, 1761. Agradezco a Ricardo Candía y Luis Adrián Vargas sus esfuerzos para obtener una copia de este raro ejemplar impreso, quizá debido a la requisa de su tiempo, depositado en la Colección de Genaro García, hoy en la Biblioteca Benson de Austin, Texas.

5. Maneiro, op. cit., pp. 450-45I. 
2. José de Alzíbar, San Juan Nepomuceno, segunda mitad del siglo XviII, óleo sobre tela, $20.10 \times 14.40 \mathrm{~cm}$, Szépmuvészeti Múzeum. Budapest, Hungría. Tomada de Olga Sáenz (coord.), México en el mundo de las colecciones de arte, Nueva España, t. I, México, Azabache, p. 299.

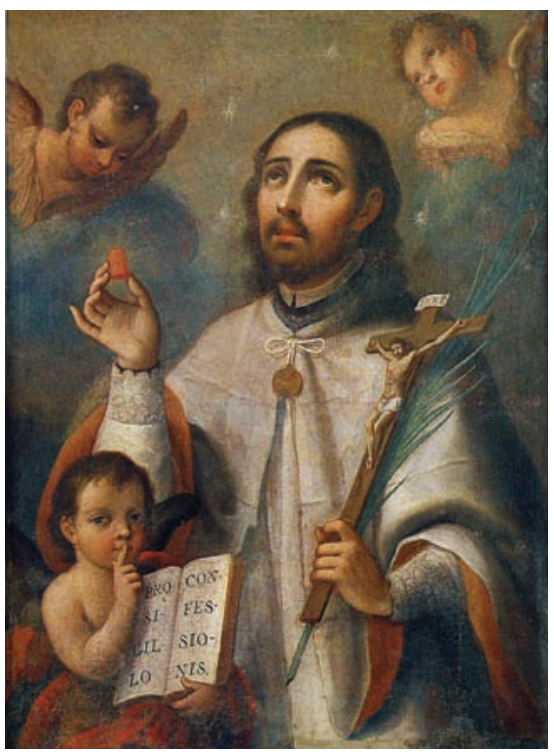

tiana crítica", el padre Clavijero despertó alguna de las pulsiones más bajas de la naturaleza humana: "Tanto irritó a un potente" quien "se juzgó ofendido por tal historia" que tal acusador no cejó en su empeño de cobrar venganza; así, este episodio, con todo y su cauda judicial, no fue pasajero ni menor en su biografía: "Esta persecución le duró mucho tiempo, le hizo padecer mucho, pero en nada le quitó la paz de su corazón, que no estribaba en modo alguno en cosas de la tierra". ${ }^{6}$

De esta manera, Clavijero conoció en carne propia las mordeduras de la intriga, la infamia, la maledicencia y, sobre todo, la calumnia. Todo por obra de la susodicha venganza que es en sí misma autodestructiva y ridícula, y se revierte para quien escucha sus torcidos oráculos. Para contrarrestar los efectos del ataque, concluye el biógrafo, "recurría a Dios en sus oraciones y ponía por su abogado a su gran protector san Juan Nepomuceno de quien era cordialmente devoto y a quien recurría en todas sus necesidades con muy fundadas esperanzas de obtener todo bien, como siempre lo consiguió" (fig. 2). Hizo entonces un voto o promesa "bajo juramento" pagando al santo con una moneda semejante; así, según su correligionario Maneiro, se comprometió a escribir un libro de su

6. Trabulse, op. cit., p. 43 . 
vida y milagros, a sabiendas de que "no había pensado ofender a nadie" y confiado en un milagro "con tal de que se apaciguara aquella imprevista tormenta"?

Sin embargo, al poco tiempo encontró en la obra del jesuita italiano Cesare Calino una inmejorable hagiografía que hacía vano su intento, y entonces, finalmente, según el padre Félix de Sebastián, modificó su promesa: "Y para dar muestras de su amor a tan gran santo tradujo del italiano al español su vida que la dio a la imprenta con gran aplauso de todos, promoviendo en cuanto alcanzaban sus fuerzas el culto y devoción a dicho santo". ${ }^{8}$ La obra se publicó en 1762 con pie de imprenta del Colegio de San Ildefonso, bajo el título de Compendio de la vida, muerte y milagros de san Juan Nepomuceno y se vino a sumar a una catarata de literatura nepomuciana que desde la segunda década del siglo inundaba las prensas y se reflejaba en innumerables retablos y pinturas por toda la geografía del virreinato de la Nueva Espańa (fig. 3). En su breve prólogo, Clavijero se identificó con el autor italiano, que había padecido el mismo mal de la intriga y la difamación, y no desperdició la oportunidad de volver a confesar su confianza en el santo y su preferencia por la veracidad y exactitud de lo allí expuesto:

El motivo que me impelió a traducirla fue el mismo que para escribirla tuvo su autor. Él la escribió para dar un público testimonio de su gratitud. Yo, que también he sentido los efectos de la beneficencia de san Juan Nepomuceno, me obligué con voto a traducirla, para dar alguna muestra de mi reconocimiento. ${ }^{9}$

Me gustaría traer aquí, para analizarlas, varias configuraciones iconográficas en que el imaginario piadoso de Clavijero bien pudo mirarse, a modo de espejo, y a satisfacción de sus devociones más íntimas, a la manera de un concitador o agencia social, en que las imágenes de culto son vehículos funcionales para la proyección personal de los devotos, más aún en medio de las venturas o desventuras de la vida.

7. Maneiro, op. cit., pp. 450-45 I.

8. Trabulse, op. cit., p. 45

9. Cesare Calino, Compendio de la vida, muerte y milagros de san Juan Nepomuceno, escrito en lengua italiana y traducido a la castellana por el padre Xavier Mariano Clavijero, México, Imprenta del Real y más Antiguo Colegio de San Ildefonso, I762. El único ejemplar que se ha podido localizar está en la biblioteca de la Universidad de las Américas-Centro Interactivo de Recursos de Información y Aprendizaje, en Cholula, Puebla, y está ilustrado con una estampa de José Morales, cuya lámina se abrió en México. 
3. César Calino, portada del Compendio de la vida, muerte y milagros de san Juan Nepomuceno, escrito en lengua italiana y traducido a la castellana por el padre

Xavier Mariano Clavijero, México, Imprenta del Real y más Antiguo Colegio de San Ildefonso, I762. Centro Interactivo de Recursos de Información y Aprendizaje, Acervos digitales, Acervo Antiguo de la Biblioteca Franciscana, Universidad de las Américas, Puebla.

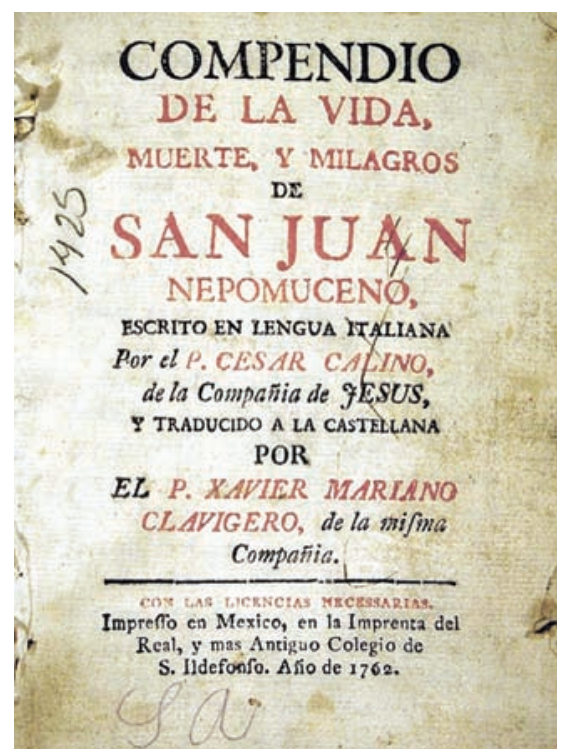

Igual que otros tantos hombres y mujeres de letras, acusados falsamente de ofensas o conductas que jamás cometieron, nuestro autor padeció los embates de la injuria y, sin duda, la envidia. Ante las acusaciones de falta de respeto o plagio, la obra sólida y consecuente del historiador veracruzano ciertamente se alzaba como una amenaza al poder "de las autoridades", de las plumas "peripatéticas" atrincheradas en los foros y los claustros y opuestas a las reformas educativas entre los jóvenes de la temprana Ilustración. ${ }^{\mathrm{IO}}$ Tales defectos eran aún más notables entre la clase intelectual, la más suspicaz y susceptible, cuyo poder se cimentaba precisamente en la retórica de una supuesta "buena fama", el mantenimiento de la honra y el sentido del decoro, si bien en las prácticas sociales todo se enunciaba u ocultaba bajo el ropaje del disimulo o, de plano, del cinismo y la autocomplacencia. Se trataba, pues, de las peculiaridades de la "moral" dieciochesca para dominar mediante las estratagemas del discurso. ${ }^{\text {II }}$ Bien se sabe que como "abanderado" de la renovación del pensamiento

Io. Dorothy Tanck de Estrada, "Tensión en la Torre de Marfil. La educación en la segunda mitad del siglo XviII mexicano”, en Ensayos sobre la historia de la educación en México, México, El Colegio de México, I98 I, pp. 23-I I4.

I I. Véase Fernando Rodríguez de la Flor, Pasiones frías, secreto y disimulación en el barroco hispánico, Madrid, Marcial Pons, 2005, pp. 205-246. 
—y bajo el impulso de Diego José Abad y Rafael Campoy—, Clavijero tuvo que replegarse por momentos ante la tibieza de sus superiores "que exageradamente temían que, con las nuevas luces doctrinales, se introdujeran los errores contrarios a la religión cristiana”; pero al final no se pudo detener el impulso del nuevo espíritu educativo, para "poner al día la enseñanza y depurar la retórica" y así se establecieron las discusiones bajo el formato de "las academias" o los cenáculos extra claustro, "que hicieron posible introducir estudios nuevos sin el permiso de la Universidad". ${ }^{22}$

Más aún, durante aquellos años juveniles del historiador en ciernes, el afán de saber y cavilar lo llevó a negar su condición de autor, con tal de ver que sus ideas, reformadoras y refrescantes, tuvieran eco entre los suyos, desterrando los equívocos y explicaciones anquilosadas, ya se tratara de hacer justicia al conocimiento del pasado de los indios o al proscribir la decadencia del gusto en la literatura o bien restituir "la genuina" filosofía:

Pero su inquietud intelectual no estaba satisfecha y se dio a escribir muchos opúsculos, unos con su nombre, otro con el de uno de sus amigos o sin ninguno, para que los lectores los apreciaran en su objetivo valor, sin perjuicios favorables o desfavorables para el autor. Se veía que Clavijero no buscaba en ellos su propia gloria, sino el triunfo de la verdad, al dirimir alguna controversia histórica. ${ }^{13}$

Tengo para mí que, en su afán de conjugar la "ciencia moderna y la ortodoxia religiosa", Clavijero asumió con decisión y sin conflicto su papel de promotor de tres devociones de identidad local, por un prurito de simpatía o inclinación cultural: Nuestra Señora de Guadalupe, patrona del reino; san Francisco Xavier, patrono de las Indias Orientales y Occidentales, y san Juan Nepomuceno, patrono de la Compañía de Jesús y las corporaciones más importantes de las ciudades y obispados de la Nueva Espańa. Ya veremos en las páginas siguientes la manera en que esta suerte de "retablo interior" se hizo presente — y harto significativo- en el decurso de sus afanes humanos, intelectuales y políticos. ${ }^{14}$

I2. Tanck, op. cit., pp. 44-45.

I3. Maneiro, op. cit., p. 450.

I4. Por ahora no nos ocuparemos del santo bajo el cual fue bautizado el padre Clavijero. Baste decir que lo acompañó tutelarmente, al menos cuatro veces, a lo largo de su vida: como estudiante en el noviciado de San Francisco Xavier de Tepotzotlán; como prefecto en el colegio de San Ildefonso de México (en cuya capilla se veneraba la taumatúrgica imagen "que sudaba"); como profesor de lenguas indígenas en el colegio del mismo nombre en Puebla, y por último, 
4. Marcos Fernández, San Juan Nepomuceno, I775, óleo sobre tela, s. m., iglesia de San Juan Nepomuceno, Saltillo, Coahuila. Foto:

Cecilia Gutiérrez. Archivo Fotográfico Manuel Toussaint, IIE-UNAM.

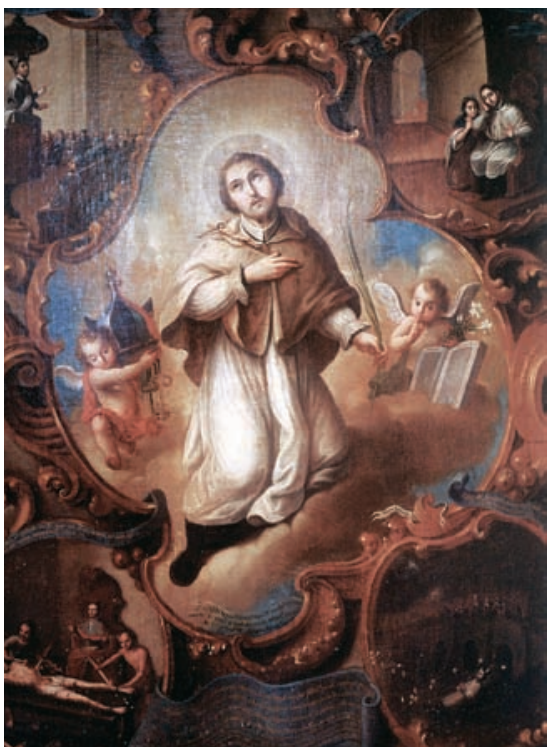

Luego de la abundante iconografía guadalupana y josefina del siglo XVIII, no hay otra más rica y diversa en el contexto novohispano que la del santo mártir, canónigo de Praga, ahogado por una turba de esbirros en el río Moldavia el I 6 de mayo de 1383 (para otros, esto sucedió en realidad el 20 de marzo de 1393) (fig. 4). Todo por haberse resistido al despotismo y los caprichos del emperador Wenceslao de Bohemia, enfurecido por los celos y cuya esposa Juana, mujer piadosa, tenía en san Juan a su confesor de cabecera. En verdad se trata de un santo tardomedieval con perfiles más legendarios que reales y que, cumpliendo con su ministerio sacerdotal, se dice, padeció con estoicismo la tortura del tirano (precisamente por no revelar el secreto de confesión de su consorte). En realidad, se piensa que todo sucedió en medio de un conflicto de potestades entre la autoridad temporal y el arzobispado, alentado por el antipapa Clemente VII de Aviñón, quien buscaba aliados para legitimarse a cambio de favores y absoluciones otorgadas a pedido. Al cabo, pagando con

al momento de morir, cuando se encomendó a su memoria, ya que según el padre Sebastián "le amó entrañablemente". Véase Jaime Cuadriello, "Xavier indiano o los indios sin apóstol", en Ricardo Fernández Gracia (ed.), San Francisco Javier en las artes. El poder de la imagen, Pamplona, Gobierno de Navarra, 2006, pp. 200-233. 
su vida la guarda del silencio, san Juan quedó proclamado como emblema de una Iglesia perseguida y asediada por el poder temporal, ya durante el naciente siglo de la Ilustración; pero también en un argumento más para oponer a éste la supremacía del secreto eclesiástico o aquella misma razón de estado, para que los órganos y miembros del "estado eclesiástico" quedaran sustraídos de las leyes de los hombres o ajenos a la transitoriedad de sus regímenes políticos. Era obvio que así también quedaba encumbrada la figura del confesor real, mediante un envase martirial y por demás emblemático: Nepomuceno, reputado como doctor en cánones por la Universidad de Padua, jamás se retractó de su ministerio y así puso a salvaguarda la institucionalidad de su iglesia local y, sobre todo, los intereses del papa legítimo de Roma.

No por nada un habilísimo consejero político de la Corona austriaca, el cardenal jesuita Álvaro Cienfuegos, se interesó tanto en canonizar la figura de este oscuro mártir del siglo xiv, y así también lo hizo jurar patrono de toda la Compañía de Jesús, justo cuando se dejaban sentir las primeras voces que cuestionaban la influencia de los padres ignacianos entre las cortes de Europa. Cienfuegos mismo, un asturiano que tomó el partido austracista, había padecido el desprestigio y la expatriación al encumbrarse la dinastía borbónica en España, luego de la guerra de sucesión. Así también hay que interpretar la denodada promoción que este cardenal hizo de la santidad de Francisco de Borja, otrora duque de Gandía, consejero de Carlos V y grande de Espańa: lo mismo que el fidelísimo Nepomuceno, ambos pueden verse como apologías del tradicional vínculo que debía conservarse entre nobleza, sacerdocio y monarquía. ${ }^{\text {Is }}$ Para todo ello, los jesuitas habían sido experimentados formadores del grueso de los "validos" y "privados" colocados en la corte y de las noblezas locales que, tejiendo redes, pilotaban la nave del estado del llamado "rey planeta". En otras palabras: del monarca hispánico erigido como un paladín católico que estaba llamado a desempeńarse como garante de la fe y príncipe universal, de la misma manera que la Compañía se enseñoreaba sobre las cuatro partes del mundo.

Con la llegada de Felipe V al trono de España, "el confesor del Rey" adquirió una influencia jamás vista, y eso, obviamente, aumentó todavía más la animadversión a la Compañía entre sus muchos malquerientes. ${ }^{16}$ Los ataques

I 5. Véase Jaime Cuadriello, "La urna como jeroglífico, Francisco de Borja, despojo y reliquia", en Rafael García Mahiques (ed.), La interpretación de las imágenes como historia cultural, Valencia, Biblioteca Valenciana, Sociedad Española de Emblemática, 2008, pp. 59-84.

I6. Teófanes Egido, "El siglo xvirI: del poder a la extinción", en Teófanes Egido (ed.), Los jesuitas en España y en el mundo hispánico, Madrid, Marcial Pons, 2004, pp. 234-239. 
a confesores, como los padres Pierre Robinet, Gabriel Bermúdez y Francisco Rábago, no cesaron hasta conseguir su caída o demonizar su prestigio, ya que en verdad se comportaban como "consejeros" ex oficio: lo mismo en la provisión de obispados y dignidades que influyendo directamente en el ánimo real para la abdicación (del mismo Felipe V) e, incluso, dando un giro más beligerante y tenso a la relación con Roma, apoyando el regalismo espańol e incrementando sus derechos sobre el patronato real.

De toda esta agenda apologética del cardenal Cienfuegos tomó nota en México el padre Juan Antonio de Oviedo y así, desde 1727, también escribió y publicó una larga vida del mártir Nepomuceno, incluso dos años antes de que tuviera lugar su canonización en Roma. Es aún más notable que la obra de este jesuita de la provincia mexicana fuera traducida al italiano y que haya aparecido en Roma un par de años después, en I729, justo el año de su ascenso a los altares. Más tarde, Oviedo declaró sin ambages la funcionalidad eminentemente defensiva del culto al nuevo santo:

Ésta bien y asegurada persuasión movió a nuestra mínima Compañía que por especial permisión de su adalid y capitán Jesús, desde que se fundó en el espacio de los siglos, siempre ha sido y es combatida en su crédito y su fama por las malignas lenguas de los herejes, que temen en el afianzado crédito de su santidad y letras, su fatal y mayor ruina; y también por muchos de los católicos, gobernados por la ignorancia o por la envidia, a que en la última Congregación General [en Roma y número I6], de I73 I escogiese a san Juan Nepomuceno como especial patrón y tutelar de su buena fama y nombre, siendo un espejo cristalino, expuesto a que el odio, la envidia o la ambición lo empañen con maligno aliento, era muy conveniente tener un protector y tutelar de superior virtud, que con la sombra de su amparo y patrocinio la defendiese de las impías y venenosas lenguas. ${ }^{17}$

No debe sorprender el activismo internacional de un jesuita tan avispado como Oviedo, quien llegó a ser dos veces provincial en México, y, con esa autoridad, en 1749 escribió una fervorosa novena de tanto éxito que fue traducida al idioma tagalo y publicada en Filipinas. Ya el santo mártir de Praga se alzaba como

I7. Éste fue el parecer, tan significativo, del padre Oviedo cuando el padre Nicolás Segura tradujo y editó en México, en 1733, la vida escrita por el padre Francesco Maria Galluzi, que había aparecido en Roma en 1719, considerada la obra de mayor alcance y divulgación del culto. Véase Pavel Stepanek, "San Juan Nepomuceno en el arte mexicano", Cuadernos de Arte Colonial, núm. 7, 1991, pp. 54-55. 
un estandarte más de la propaganda de los jesuitas, en los precisos tiempos en que desde la cima del poder — e identificados con el poder mismo- otros muchos intrigantes socavaban los cimientos de su edificio político y cultural, presagio de su ruina y sus desgracias por venir.

A partir de la exhumación de los restos juaninos en la catedral de San Vito de Praga en I719 y del significativo prodigio de hallar incorrupta su lengua (que a la vista de todos empezó a palpitar), esta devoción alcanzó a mover la piedad de innumerables fieles y, valga decirlo, fue utilizada a conveniencia de las regiones y grupos de poder. La lengua enrojecida, prodigioso indicador de la guarda del sigilo - y de hecho el milagro necesario para sancionar el proceso-, fue extraída del cuerpo y depositada en una redoma y así quedó expuesta a la veneración en la abadía de Zelena, su región natal, a modo de una reliquia "apotropaica" o para alejar el mal de ojo, atrayendo a infinitos peregrinos. La fiesta de su canonización en Praga en octubre de I729 ha sido considerada la de mayor esplendor barroco en Bohemia y epítome de su patriotismo regional; desde entonces, san Juan hizo pareja simbólica con san Carlos Borromeo, arzobispo de Milán. Así, pues, ambos quedaron proyectados por la iconografía como paradigmas de la "cura Pastoral", siempre en consonancia con la administración capitular - la concordia que debe reinar entre los canónigos y el pastor-, o un modelo de unión y armonía en la conducción del gobierno diocesano. ${ }^{18}$

Este fenómeno de apropiación y contestación religiosa, palpable en las devociones tardobarrocas y aquí tan imantadas por la ideología de los criollos, se manifestó de una forma por demás temprana, expresiva y peculiar, en especial para un virreinato como la Nueva Espańa, necesitado de edificar una identidad precisa y, me atrevo a decir, mediante el uso de imágenes politizadas como demandas, alegatos o representaciones de su sociedad dirigente. El culto nepomuciano también lo propagaron los jesuitas checos llegados al virreinato para misionar en el norte, pero sorprende por el arraigo tan hondo y prolongado que alcanzó en tan dilatado territorio a lo largo de toda esa centuria y buena parte del siglo XIX, más aún por provenir de una región de la Europa del Este tan remota y sin aparentes nexos culturales con nuestras latitudes.

I8. Un ejemplo iconográfico de esta dupla eclesial se miraba en el retablo de Casa Profesa realizado por Manuel Tolsá: en las calles laterales, sobre los frontones del primer cuerpo, se posa aún san Carlos Borromeo ataviado de cardenal, y su equivalente — de origen san Juan Nepomuceno- fue transformado en la segunda mitad del siglo XIX en un san Alfonso María de Ligorio (de hecho, la escultura conserva algo de su expresión gestual original). 
Basta una cita de la biografía del padre Antonio Tempis, escrita por su correligionario el croata Fernando Consag, que describe sus heroicos afanes misionando en las Californias, para mostrar el vínculo entre este nuevo santo y aquellos tiempos de malos presagios. Tempis había estudiado en la Universidad de Praga y vivió de cerca la exhumación y el proceso de santidad de san Juan y, por fidelidad a éste, hizo voto para ingresar al noviciado de la Compañía en I720. Sacerdote profeso y ya avecindado entre los indios pericúes de la Baja California, Tempis logró pacificarlos en 1736, luego del martirio de los anteriores misioneros, divulgando su devoción más entrañable:

Singularmente afecto al culto de san Juan Nepomuceno, ayunando en honra suya la víspera de su fiesta, la que celebraba con la posible solemnidad, y le pagaba diariamente tributos de devoción. Entre ellos, el que le ofreció en el propósito de no hablar nunca palabra picante, y menos alguna que pudiese desdorar la opinión ajena; y así lo cumplió, pues jamás se le oyó murmurar, ni consentir en alguna murmuración y esto aún cuando era pública la culpa, en que si no podía el hecho, excusaba la intención. ${ }^{19}$

Más allá de esta tradicional protección, su devoción y paisanaje sanjuanista fue un eficaz auxiliar en sus estrategias persuasivas dirigidas hacia aquellos indios de naturaleza contumaz y feroz, que miraron cómo el mártir los proveía de pescado - a través de un gavilán posado en una palma- o reactivaba un venero de agua para no verse forzados a mudar la misión a otro paraje. No por casualidad pez y aguas eran parte de los atributos personales de san Juan, uno por ser emblema de la creación muda y las otras por brindar un lecho de remanso a su cuerpo martirizado. En suma, "siendo tan obsequiado el santo de su cliente, correspondió a los obsequios con algunos favores extraordinarios" y, para cumplimentar la promesa, Tempis correspondió igualmente y así "fabricó una capilla con su retablo". Todo esto hizo para expandir este culto en aquel punto tan occidental, sin duda el más, en los territorios de la monarquía española (y cumpliéndose apenas un lustro de la canonización sanjuanista en Roma). ${ }^{20}$

19. Fernando Consag, Carta del visitador de las misiones de las Californias a los padres superiores de esta provincia de Nueva España, María Eugenia Ponce Alcocer (est. prel. y trans.), México, Universidad Iberoamericana, 2005, pp. 68-72.

20. Clavijero, en su historia de la península bajacaliforniana, confesó su admiración por las virtudes de ambos hombres apostólicos, aunque se reservó avalar del todo la veracidad de los milagros que ocurrieron a Tempis: "Los luminosos ejemplos de su vida le conciliaron la reputación de santo entre los que eran testigos de ellos, los cuales referían también algunas cosas extraordi- 
En las ciudades el fenómeno resulta igualmente sorprendente. Ya en 1724 los oidores de la Audiencia de México formaban una congregación acogida a la figura de este nuevo santo (sita en la iglesia del hospital del Espíritu Santo donde tuvo su primer retablo), invocando sus poderes como canonista para que la magistratura del reino, a su cargo, se condujera con imparcialidad y probidad, o tal vez para restituirse del desprestigio a que la sometían los visitadores por aquellos años, en que algunos de sus miembros se dijeron atacados por la maledicencia. ${ }^{2 \mathrm{I}}$ No por acaso su principal impulsor era el oidor criollo y "protector" de la Real Audiencia Juan Manuel de Oliván Rebolledo, un brillante jurista y asesor de virreyes que a su regreso de la metrópoli padeció la difamación, a decir de Beristain: "A pesar de los tiros que le asestó la envidia, fue uno de los tres únicos ministros, que no depuso en su pesquisa el visitador de la Nueva España el Ilustrísimo Francisco Garceron". ${ }^{22}$

Lo mismo hizo el Real Seminario y poco después el Real Colegio de Abogados, para que así su desempeño en la jerarquía o en el foro no se viera comprometido por la fuerza de los intereses pactados; y en I 743 también se sumó a su patronato el claustro de doctores de la Universidad de México, a sabiendas de que el santo era garante de la liberalidad del conocimiento, incluso más allá de la injerencia del rector en turno, sus allegados y del propio virrey que fungía como su vicepatrono. A la solemne función anual de la capilla universitaria concurrían también, por invitación fraterna, los jóvenes estudiantes del colegio de San Ildefonso y los seminaristas del Real y Tridentino, con sus becas respectivas, para dar muestra pública de la concordia que debía reinar entre el saber y el poder, entre los eméritos con autoridad moral y los noveles

narias que el vulgo tuvo por milagrosas; mas nosotros como no las creemos del todo superiores a las fuerzas de la naturaleza, no dudamos que serían gracias particulares del cielo alcanzadas por los méritos de este fiel siervo de Dios". Francisco Xavier Clavijero, Historia de la Antigua o Baja California, Miguel León Portilla (pról.), México, Porrúa, 1970, p. I99.

2I. Entre I72 I y I725, la audiencia quedó sacudida por su forzada recomposición entre oidores criollos y peninsulares, con desventajas para los primeros. Véase Mark Burkholder, De la impotencia a la autoridad: la Corona española y las audiencias en América, 1680-I808, México, Fondo de Cultura Económica, 1984, pp. 60-6I. Acerca de la muy interesante y original figura de Oliván, como primer criollo mercantilista y reformador, puede consultarse Iván Escamilla González, "Juan Manuel de Oliván Rebolledo (I676-I738). Pensamiento y obra de un mercantilista americano", en María del Pilar López y Leonor Ludlow (coords.), Historia del pensamiento económico. Del mercantilismo al liberalismo, México, Universidad Nacional Autónoma de México-Instituto de Investigaciones Históricas, 2007, pp. I09-I 30.

22. José Mariano Beristain y de Souza, Biblioteca hispanoamericana septentrional, México, Universidad del Claustro de Sor Juana, I98 I, p. 392. 
5. Anónimo, San Juan Nepomuceno (como doctor), segunda mitad del siglo XVII, óleo sobre tela, s. m., Museo Regional de Guadalajara. Foto: Pedro Cuevas, 1979. Archivo Fotográfico Manuel Toussaint, IIE-UnAm. Conaculta-INAH-MÉX.

"Reproducción autorizada por el Instituto Nacional de Antropología e Historia”.

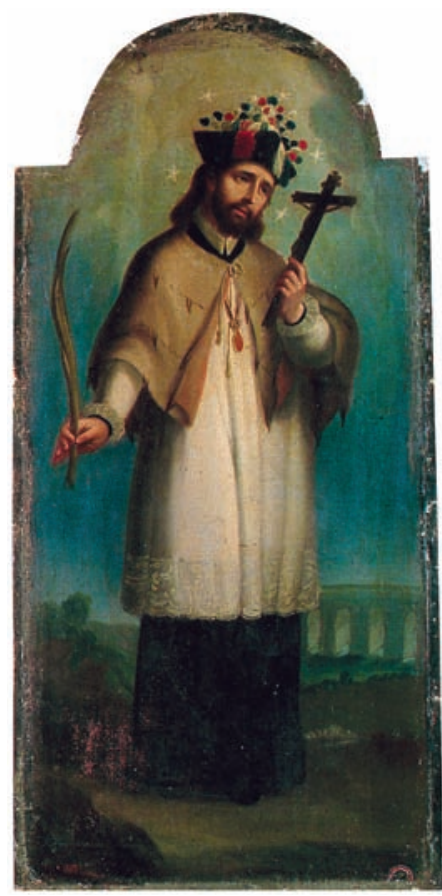

con legítima aspiración, y más allá del cargo y el grado (de hecho, el panegírico literario corría a cargo de los jóvenes como deferencia de los mayores a los talentos de los menores); de allí que en ocasiones, en sus imágenes, san Juan luzca el birrete doctoral con las cuatro borlas (las sendas facultades) que alude a los grados que obtuvo en Padua, pero con la forma y las características de los birretes de los doctores novohispanos (fig. 5).

Hay otros muchos ejemplos en el anecdotario virreinal y decimonónico que prueban la efectividad de los poderes de este santo, que no sólo era invocado como principal protector de la guarda del sigilo y el secreto de confesión, sino que, en medio de las pequeñeces de la vida diaria, se creía que inmunizaba a sus devotos contra el chisme, la maledicencia, la murmuración, la injuria y la calumnia. En suma, un santo varón protector con un amplio espectro social: de la honra propia y la del prójimo, incluso, aunque se tratara de nuestros más encarnizados enemigos.

Basta mirar, por ahora, una peculiar iconografía de gusto rococó aparecida en la segunda mitad del siglo XviII, que muestra de manera palmaria esos 
poderes, en verdad tan necesarios y apreciados, para sobrevivir en una estrecha sociedad de contrastes y disimulación, donde la calidad de las personas prohijaba tanta "altiva bajeza" o "grandeza caída".

Montado sobre los nimbos de su apoteosis o en el momento en que recibe la corona del martirio, san Juan aparece con su stellarium de cinco luces punteando su cabeza, que alude a la glorificación de su cuerpo rescatado de las aguas del río. Al mismo tiempo, desde las alturas, blande su lengua rojiza como si se tratase de un elocuente gesto de pronus, que, en efecto, despierta la atención de sus devotos (fig. 6a). Nótese que, por medio de las centellas que emanan de esta reliquia corporal, alcanza y fulmina a un perico parlanchín, de cabecilla moteada, y a una gorgona enfurecida y abatida; en realidad, vemos a un ente monstruoso de mirada torva, senos flácidos y cabellos serpentinos (también conocida personificación de la Injuria, la Discordia y la Envidia). Un angelote igualmente colabora a este acto de extinción, oponiendo el bonete nepomuciano a un áspid que emerge de la trompeta de la difamación, en clara referencia a las antípodas de su reliquia: las terribles lenguas viperinas. De tal suerte se impide que se propaguen la mentira, la calumnia y las malas palabras a favor de todos aquellos que se han sentido agraviados o que pretenden hallar satisfacción con las desgracias ajenas (dada la pequeñez de sus sentimientos, razonamientos y saberes).

Considero, pues, que esta alegorización de los pecados del habla — de la cual he podido localizar tres ejemplos- mantenía una funcionalidad muy precisa dentro de las comunidades eclesiásticas, en especial entre los cabildos catedralicios y las corporaciones, donde la estima de la concordia y la buena fama era un valor que a menudo se perdía en medio de las disputas institucionales por las prebendas, los grados universitarios o los simples celos personales. Es decir, esta aniquilación de las personificaciones de la incontinencia verbal sin duda tenía un papel admonitorio para todos aquellos que quebrantaran la discreción y la guarda del silencio. Estamos ante una imagen en la que no sólo se hace ostensible el poderío del santo o sus especialidades para dispensar protección, sino que se fustiga virtualmente a los posibles infractores mediante un dispositivo visual semejante al de un Pantocrator iracundo y tonante. Así, merced a los recursos de un discurso analógico, aquellos murmuradores de lengua filosa o ponzońosa se podían mirar humillados con la misma fuerza de una descarga eléctrica, tal como en una vívida exempla puesta a la vista de todos para valorar y practicar las virtudes del silencio. En otras palabras, por medio de esta imagen se podía apreciar el efecto aniquilador de la incorruptible len- 
gua nepomuciana, tan sólo haciendo la trasnominación de la serpiente, el loro y el monstruo en aquellos apelativos propios que nos vinieran a la mente, patentizando de manera contundente la proverbial protección sanjuanista.

El conceptuoso didascalio que se lee en uno de estos cuadros, a modo de inscriptio labrado sobre un basamento pétreo, no sólo promueve y asegura las virtudes del que calla, sino que establece un curioso parangón entre la imagen del santo y la función de la pintura, en tanto predicador mudo. Nótese cómo se equipara el oficio del pintor, según la mimesis, con la imagen real y virtual de la santidad:

Si de otro que de Juan imagen fuera

Bien que Artífice diestro lo sacara

Conforme al natural, ya se dijera

Que no faltaba más sino que hablara.

Mas, si ella ha de pasar por verdadera

Del Gran Nepomuceno (¡cosa rara!)

Le está bien el silencio, en nada falla

Y aún es más parecida, porque calla. ${ }^{23}$

Entre el arquetipo hagiográfico y el prototipo pictórico tiene lugar la emulación retórica y, al cabo, la enseñanza moral: "Y aún es más parecida, porque calla". No es una casualidad, entonces, que esta última imagen haya llegado del todo funcional e in situ hasta 1976 cumpliendo con su original cometido admonitorio o para salvaguarda de la armonía institucional de una corporación. Es la misma que hoy conserva el Museo de la Basílica pero que tenía el honor, nada menos, de guarecer el revés de la imagen original de Nuestra Señora de Guadalupe en su antiguo santuario del Tepeyac. O, en otras palabras, era la imagen de culto central que se miraba desde todos los sitiales del nuevo coro semicircular, trasero al trono de la Virgen, al menos desde finales del siglo XIX (cuando se trasladó el coro). No sólo tiene las mismas medidas que el Sagrado Original, sino que, merced a su elevación en ese sitio de privilegio, bien podemos imaginar que los rayos que se disparan desde la lengua podían

23. Esta octava es la misma que aparece como preámbulo en la obra del poeta de Valladolid (hoy Morelia) José Agustín de Castro, El triunfo del silencio, canción heroica que al glorioso martirio del inclito sagrado protector del sigilo sacramental san Juan Nepomuceno, sácalo a luz el Señor Conde de Miravalle, quien lo dedica a María Santísima de Guadalupe, México, Imprenta de Felipe Zúńiga y Ontiveros, 1786. 

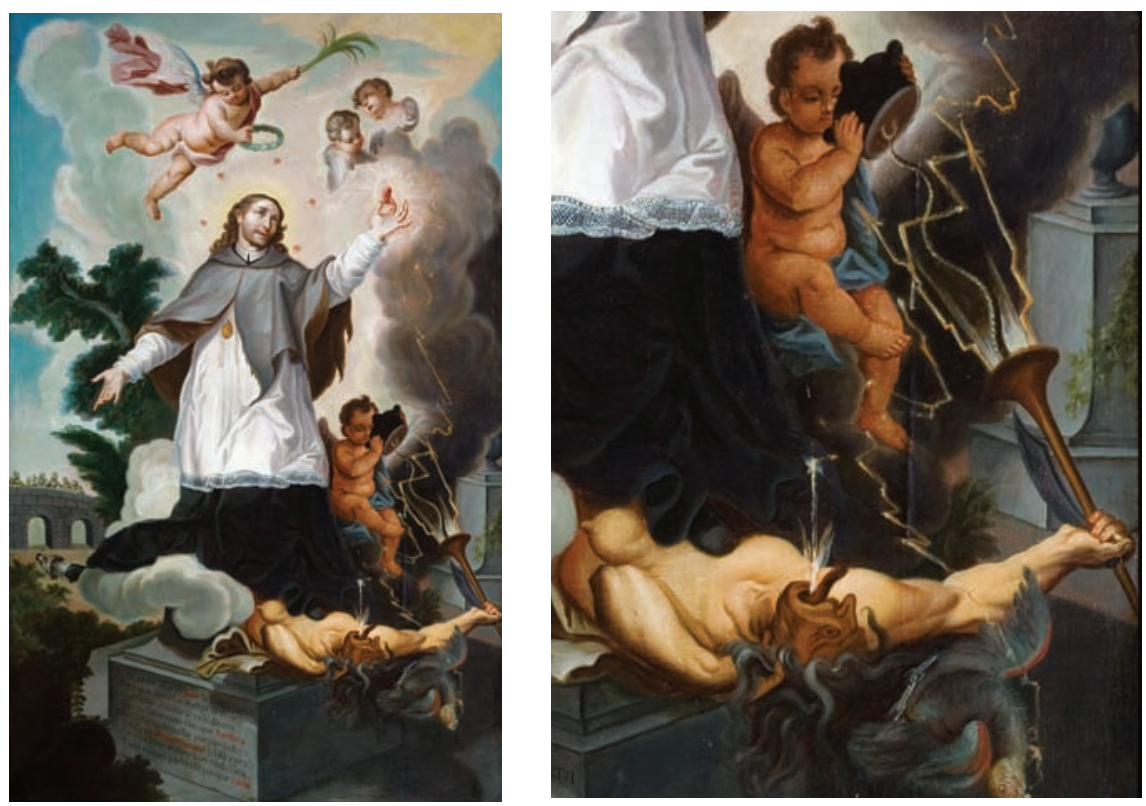

6a) Anónimo novohispano, San Juan Nepomuceno, siglo xviII, óleo sobre tela, $209.3 \times$ I26.6 × 2.8 cm (sin marco). Foto: Eumelia Hernández. Colección Museo de la Basílica de Guadalupe; b) detalle.

alcanzar hasta los sitiales de los canónigos potencialmente inquietos o belicosos (sobre todo los que vociferaban en contra de la tradición aparicionista de la imagen desde las sombras). Lo mismo que al loro, el áspid o la furia, los poderes de Juan tenían un efecto fulminante según la moraleja bien aprendida por los espectadores: "Le está bien el silencio, nada falla" (fig. 6b).

Todavía puede verse al centro del coro de la catedral de Puebla, erguida sobre el facistol, la escultura estofada de san Juan puesta allí desde el ocaso del siglo XviII como un dispositivo para provocar semejantes respuestas. En el punto más visible de estos espacios neurálgicos, la figura de san Juan era una suerte de garante de la vida colegiada de la institución (las decisiones consensuadas según las categorías de Óscar Mazín), y así el cabildo hacía patente sus deberes de corresponsabilidad en el gobierno y construía una 
tradición propia, como un asunto de identidad cultural y moral por demás pertinente. ${ }^{24}$

Basta ver cómo en el mismo lenguaje coloquial quedó presente esta admonición, o en los ecos que aún recogen los refranes y dichos y que emplean la misma estrategia de ataque/prevención del didascalio, quizá prolongando la fuerza de los rayos nepomucianos sobre la conciencia y, consecuentemente, en los actos de la vida cotidiana. Por ejemplo, hablando de Clavijero y de Puebla y sin afán de ofender, es oportuno recordar aquí aquel refrán tan manido y repetido que nos previene que:
Mono, perico y poblano
No los toques con la mano;
Cógelos con un palito
que son animal maldito

Se trata de una cuarteta de mal gusto pero que en verdad comparte con esta imagen alegórica una intencionalidad similar, o al menos concomitante, dada la presencia tan obvia del ave parlante y el ofidio, detenidos e inmunizados con el bonete nepomuciano (y por el ofidio aquí se estaría trasnominando al "poblano", ya que termina como "animal maldito" según la historia de la expulsión del Génesis). El "mono", tengo para mí, es quizá un mote para referirse a un engendro ("figura híbrida o deforme representada", según el diccionario), en este caso a la enjuta personificación de la Envidia y la Maledicencia, tradicionalmente figurada en una anciana jorobada y bizca, ya estéril (por eso los senos flácidos), de pensamientos truculentos y perversos (por eso la cabellera de serpientes), de dientes podridos y aliento herrumbroso (porque su verbo es un vómito de sus propias vísceras), que se revuelca entre fuegos al saberse derrotada, tal como se figuraban los herejes enemigos de la Iglesia en el discurso de los carros triunfales contrarreformistas. En su Theatro moral de la vida humana en cien emblemas, el emblemista neoestoico Otto van Veen representaba a la Envidia tirada en un erial con su cabellera de serpientes, arrancándose una de ellas con un ademán de furia y rencor, para arrojarla sobre sus antagonistas (símbolo de "sus pensamientos mortíferos") (fig. 7). También se le mira al lado de su inseparable mascota, el perro sabueso y ladrador, que la acom-

24. Óscar Mazín, El cabildo catedral de Valladolid de Michoacán, Zamora, El Colegio de Michoacán, 1996, pp. 32-37. 
paña a todas partes como emisario y mandadero, ya que a menudo rińe con otro perro en pos del mismo hueso (que son los honores y cargos venidos del poder). En su declaración a esta figura, el sabio maestro de Rubens advierte, emulando en esto al emblema 7I de Andrea Alciato: "Este solo vicio carece de algún deleite; este solo trae consigo el castigo de sí mismo; se revuelca y se emponzońa con su mismo veneno; todo es ira, todo furor, todo es rabia, hasta comerse su mismo corazón". ${ }^{25}$

En este mismo sentido, he aquí otra joya de la sátira vernácula, aunque ya del siglo XIX, enderezada contra las malas conciencias que, según la tradición de la capital, poblaban la susodicha Angelópolis, a quienes se retrata precisamente como a los personajes herejes y apóstatas confinados en un antro o en un ambiente ígneo y subterráneo:

En un alambique echarás

a un ladrón y un asesino

a Lutero y a Calvino

a Herodes el inhumano;

y en la hornilla de Vulcano

y con un poco de paciencia

obtendrás la quintaesencia

de un legítimo poblano. ${ }^{26}$

Y, aunque sea de paso, no por casualidad están allí otros dos testimonios de la misma paremiología mexicana para dar cuenta de la proverbial ojeriza contra los poblanos y, sobre todo, para fustigarlos y ponerse a resguardo de sus temibles habladurías:

\author{
Lenguas y campanas, \\ tan sólo las poblanas \\ Para chismes y campanas, \\ Zacatlán de las Manzanas.
}

\footnotetext{
25. Otto van Veen, Theatro moral de la vida humana en cien emblemas, Amberes, Imprenta de la Viuda de Henrico Verdussem, I733, pp. 60-6r. También puede verse el estudio de Santiago Sebastián sobre este libro en "Theatro moral de la vida humana. Lectura y significado de los emblemas", Boletín del Museo e Instituto Camón Aznar, Zaragoza, vol. XIV, I983, p. 2 I.

26. Darío Rubio, Refranes, proverbios y dichos mexicanos, México, Márquez, I940, t. I, pp. 330-33 I.
} 
7. Otto van Veen, Theatro moral de la vida humana en cien emblemas, op. cit. (vid supra n. 25), emblema 30: la Envidia.

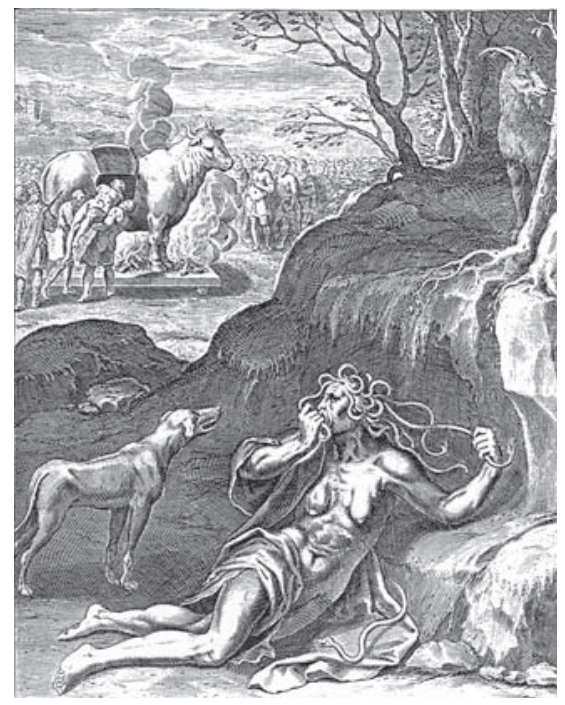

Aquí hay que entender que las campanas adquieren un significado semejante al de las lenguas o que se desempeñan como vehículos comunicativos que publican, a voces, todo aquello que debe mantenerse en el ámbito privado. Tampoco olvidemos que entre las varias vidas de san Juan Nepomuceno escritas en la Nueva España, una de ellas lo motejaba en el título como El milagroso bohemio y harpócrato cristiano; y es claro que el culto al silencioso dios Harpócrates era bien conocido entre la clase acomodada de la sociedad criolla, merced a los biombos que reproducían los modelos emblemáticos de Otto van Veen y su virtuosa ponderación del silencio (mediante el gesto del tacere o con dedo índice oprimiendo los labios), conforme a su emblema 29 que lleva por mote "Nada más provechoso que el silencio" (fig. 8). ${ }^{27}$

En este sentido, otro gran devoto del santo había sido el canónigo y abogado de Valladolid de Michoacán Miguel de Reyna Ceballos, quien erigió un altar en aquella catedral y publicó en Madrid en 1738 su extenso poema heroico sutilmente intitulado La elocuencia del silencio. ${ }^{28}$ Este criollo dedicaba su libro, de manera por demás significativa, al padre Guillermo Clerk, con-

27. Van Veen, op. cit., pp. 58-59.

28. Mazín, op. cit., p. 338. 


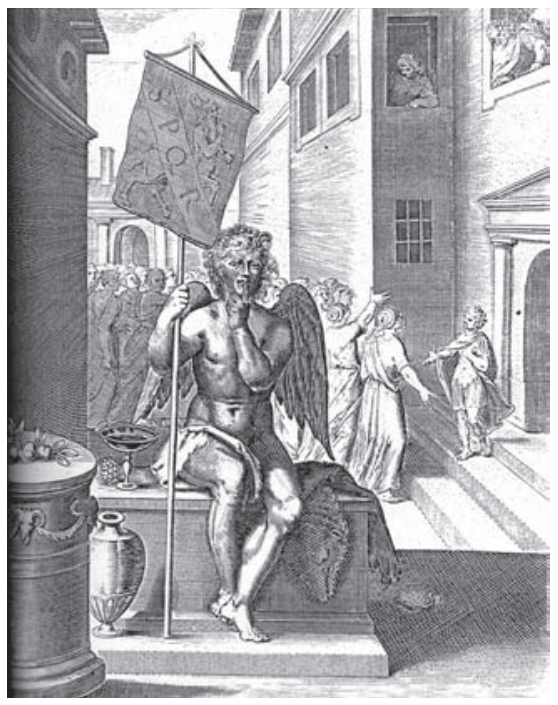

8. Otto van Veen, Theatro moral de la vida humana en cien emblemas, op. cit. (vid supra n. 25), emblema 29: "Nada más provechoso que el silencio".

fesor jesuita de Felipe V, y así declaraba que la reciente proclamación de san Juan Nepomuceno como "numen tutelar del gobierno de la Sagrada Jesuítica familia" era un buen augurio para que Clerk se desempeñara con éxito en su "real ministerio", honrando la memoria del mártir de Praga:

Fía la Católica Majestad de nuestro Rey y Señor (que Dios Guarde) al religioso, sabio, prudente de Vuestra Seńoría Ilustre [Clerk] las llaves de su conciencia, así en los supremos destinos, haciendo eco las reales direcciones, [...] siendo su corazón sagrado cauce de sus reales arcanos.

El confesor real debía, pues, corresponder a la figura de "un santo cortesano, de un santo palaciego" pero que, renunciando a las comodidades y la adulación, devino en "santo héroe". 29

Hablemos aquí de otro recurso admonitorio o hasta cierto punto un dispositivo extremo: una hoja volante a manera de juramento piadoso y disuasivo o de indulgencia sui generis para librarse de las penas del purgatorio. Avalado por el mismo obispo de Puebla, se trataba en realidad de una suerte de contra-

29. Miguel de Reyna Cevallos, La eloquencia del silencio, poema heroyco, vida y martirio del gran proto-mártir del sacramental sigilo, fidelíssimo custodio de la fama y protector de la Compañia de Jesús, san Juan Nepomuceno, Madrid, Oficina de Diego Miguel de Peralta, I 738 [dedicatoria]. 
9. Anónimo novohispano,

Oración de san Juan

Nepomuceno, 1765 , grabado sobre lámina. Colección Museo

Soumaya. Fundación Carlos Slim, A.C.

/Ciudad de México.

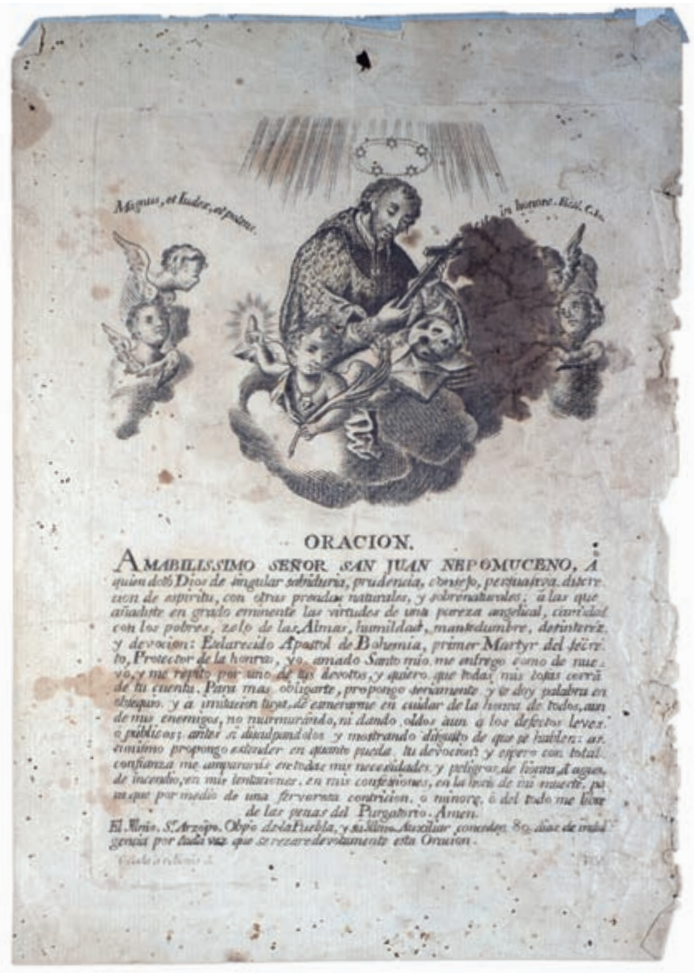

to avenido a dos partes, o entre el devoto y el santo, donde se afianzaba bajo juramento de palabra la guarda del silencio, a manera del voto por promesa:

Para más obligarte, propongo seriamente y te doy palabra en obsequio, y imitación tuya, de esmerarme cuidar de la honra de todos y aun de mis enemigos, no murmurando ni dando oídos aun a los defectos leves o públicos: antes si disculpándolos y mostrando disgusto de que hablen [de las vidas ajenas].

El mismo grabado contribuye a reforzar este efecto disuasivo: bien se mira, junto a la "mansedumbre y humildad del santo", un angelote que blande la lengua incorrupta al tiempo que sobre su cuello pende un candado que avisa sobre las ventajas de saber "que en boca cerrada, no entran moscas" (fig. 9).

De la alegoría en que se fulmina a las malas lenguas se conocen otras dos versiones, una en la catedral de León y otra en el Museo de Arte de Querétaro, 
y vale la pena regresar a ellas para dejar en claro su intencionalidad y sus funciones. La lengua enarbolada desde lo alto no sólo hace ostensibles los poderes de una reliquia y visualiza el triunfo de una nueva devoción internacional, sino que surte efecto en el ánimo de los fieles para guardarse de la propia, so pena de compartir el destino del loro, el ofidio y la gorgona. Esta colorida cuan tremenda alegorización, hemos dicho, era la cara oculta del ayate de Juan Diego, pero la más visible para que cada una de las dignidades eclesiásticas asumiera un código de comportamiento consensuado. Valga agregar que era en razón de que san Juan fue jurado patrono por el abad y los canónigos de la colegiata de Guadalupe desde I750, año de su instalación como cuerpo eclesiástico y capitular, que por primera vez gozaba de autonomía del arzobispo de México (causa de un ríspido proceso de enfrentamiento que mantuvo a esta corporación en vilo durante casi una década). Desde entonces, san Juan acompañó al abad y los canónigos en sus venturas y desventuras políticas, con la erección de un retablo y su fiesta solemne. Uno de ellos, ya en el ocaso del siglo xix, fue el mejor historiador del culto al santo de Praga en estas tierras: Vicente de Paul Andrade. No por nada fue el capitular más polémico y aguerrido, en verdad un antagonista que desafió temerariamente al poder y el canon del arzobispo por cuanto negaba la historicidad de las apariciones (inimicus homo, le llamaban sus superiores y detractores)..$^{\circ}$

Otro dato revelador acerca de estas prácticas corporativas aflora en una imagen de bulto, que permanece in situ o en medio del coro de la catedral de Puebla. Sobre el facistol giratorio, que le sirve de peana, todavía luce una escultura de tamańo natural del canónigo de Praga que, puesta en ese sitio focal, parece dirigir la armonía humana y musical del cabildo y la capilla del máximo templo de la Angelópolis. De hecho, en innumerables pinturas el santo renuncia a su esclavina de armiños (al uso de la gélida Bohemia) y queda ataviado con los ornamentos de lino, plegados y con bolillos (una muceta con encajes propiamente), peculiares de los canónigos novohispanos.

Digamos por último que el fervor novohispano alcanzó incluso el beneficio de la llegada de algunas reliquias extraídas del venerable cuerpo del mártir de Praga, siendo la más famosa un nudillo del dedo índice que trajo consigo

30. Los apuntes nepomucianos de Andrade escritos en castellano y luego traducidos al checo se publicaron en I 895. Se trata de un título rarísimo, ya que su autor sólo imprimió 24 ejemplares y el único disponible hasta hoy se halla en la biblioteca del Museo de Antropología (de origen pertenecía a la librería personal del historiador Luis González Obregón). Véase El culto y devoción a san Juan Nepomuceno en México, México, s.e., I895. 
el virrey marqués de las Amarillas en I755. Esta reliquia la había donado en Viena la emperatriz María Teresa de Austria al embajador español Antonio Azlor, con destino a la familia de los marqueses de San Miguel de Aguayo, la cual, al cabo de tres décadas, quedó expuesta con altar exclusivo en el templo del convento y colegio de La Enseñanza (I782). ${ }^{31}$

Ha quedado claro que el itinerario iconográfico y la popularidad de esta devoción en la Nueva España se extendían desde las misiones del norte hasta el recinto poderoso de las catedrales o las salas de las audiencias, pasando por los santocallis de los indígenas y los nichos de las vírgenes de clausura; y puede asegurarse, tal como lo sugirió Isabel Mateo, que luego de la expulsión de los jesuitas, sus reconocidos promotores, en 1767 el culto se exacerbó aún más y se "politizó" con tintes de resistencia, ${ }^{32}$ sobre todo por la analogía que se estableció entre este héroe de la discreción y la consecuencia sacerdotal, víctima de un tirano, y la tragedia sufrida por los hijos de san Ignacio a manos del absolutismo de Carlos III y sus ministros jansenistas. Todo sucedió en circunstancias semejantes, como el hecho de que la Compañía había padecido desde siempre la calumnia mediante feroces libelos y diatribas que volvían a circular entre sus enemigos, sobre todo entre aquellos que se sentían desplazados o que rivalizaban por alcanzar el favor de los poderosos.

Basta ver una de las tantas imágenes antijesuíticas ideadas por los seguidores del obispo Palafox que empleaban el mismo lenguaje tonante, viperino y envidioso para desenmascarar la pretendida falsedad de los teólogos ignacianos y, sobre todo, su insana cercanía con el poder, o asomarnos a la gráfica en que se escarnece a los jesuitas y se invierten los papeles que hacían de san Juan un disparadero de justicia y aniquilación del mal (fig. Io). En una de ellas vemos a una tríada de arcángeles justicieros, con sus rayos tonantes y los escudos de Francia, España y Portugal, arremetiendo contra "los padres negros" que se precipitan a los avernos para regocijo de una caterva de diablos que los

3 I. Ibidem, p. Io. De hecho, la madre María Ignacia Azlor y Echeverz, fundadora del colegio, atribuía a la intercesión de san Juan Nepomuceno la consecución de la licencia real para abrir su fundación, ya que habiendo rezado su novena llegó la feliz noticia. Véase Pilar Foz y Foz, $\mathrm{La}$ revolución pedagógica en la Nueva España, Madrid, Instituto Fernández de Oviedo / Claustro de Sor Juana, I98I, vol. I, p. 305.

32. Isabel Mateo, "Dos alegorías mexicanas de exaltación de la Compañía de Jesús tras la expulsión de la orden por Carlos III", en El arte en tiempo de Carlos III, IV jornadas de arte, Madrid, Departamento de Historia del Arte Diego Velázquez, Consejo Superior de Investigaciones Científicas, 1989, pp. 377-386. 


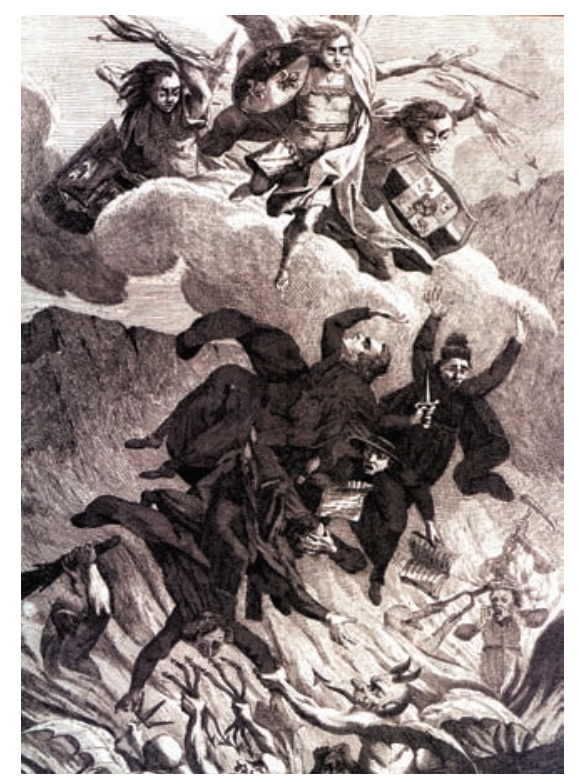

Io. Anónimo, La condenación de los jesuitas, I762, grabado sobre lámina. Biblioteca Nacional de Francia. Tomado de "Los jesuitas ante el despotismo ilustrado", Artes de México, núm. 92, diciembre 2008, p. 3.

reciben con porras, tenazas y piquetas; mientras un sacerdote ignaciano aún empuña una daga, aludiendo al regicidio, vemos a otro, ya condenado, que ciñe una corona de tortura como símbolo de un poder del que fatalmente no puede desprenderse.

Sin embargo, ante la diatriba, la respuesta de los expulsos fue el estoicismo y la resignación, pero también la crítica histórica en aras de que la posteridad los juzgara de otro modo. En un sentido sermón predicado por el padre Clavijero ante sus hermanos y paisanos en Bolonia, al conocerse la inminente supresión de la Compañía en I773, el autor asumía, con ánimo purgante, el desventurado destino que les deparaba la vida, pero no sin dejar de cuestionar la conciencia de los poderosos. En realidad, se trataba de la prueba más terrible de todas porque el dictamen procedía del papado, el eje fundacional, de fidelidad y fortaleza de la misma Compañía, que había establecido san Ignacio mediante su "cuarto voto". Así también, en esta pieza oratoria su autor dejaba ver la plena confirmación de que aquellos malos presagios, con los que 50 años atrás se había echado a andar el culto sanjuanista, verdaderamente rebasaban cualquier escenario imaginable. En otras palabras, entre el omnímodo poder de los confesores y el acecho de las potencias, que otrora cobijaban a los jesuitas-consejeros, el panorama pintado por Clavijero era desolador: 
Vemos inundado el mundo de arrestos, escritos y libelos infamatorios de nuestras costumbres, de nuestro instituto y de nuestra doctrina. Nos tratan a cada paso de soberbios, de codiciosos, de malignos, de regicidas, de corruptores de las costumbres, de herejes, de idólatras y aun de ateístas. No hay delito o error que no se nos impute. Pero creemos que en medio de tan deshecha tempestad de calumnias tenemos cubierto nuestro honor, entretanto que el vicario de Cristo se interesa en conservarlo. Mas si él nos condena como tememos, quedará autorizada la calumnia y nosotros eternamente infamados. Y entonces ¿quién será capaz de vivir cubierto de tanta ignominia? ¿quién? quien asintiere plenamente a las palabras de nuestro Redentor que llama felices a los que por Dios sufrieren la maledicencia, la persecución y la calumnia: Dichosos vosotros cuando os insulten, os persigan y os calumnien de cualquier modo por causa mía, Mateo, 5, I I. ${ }^{33}$

En efecto, la acusación más dura la reservó Clavijero contra el papa Clemente XIV por haber suprimido la orden sin abrir un proceso preparatorio, sin dejar hablar a las partes afectadas y contraviniendo, además, la legislación de los concilios y la opinión de los expertos. Todo para halagar "los reservados motivos" de las influyentes casas de Braganza y Borbón: "Tú hiciste después un proceso criminal contra sus principales miembros. Tu Breve, pues, está lleno de calumnias". Así escribía Clavijero su memorable carta de 1776, desafiando la prohibición papal de expresarse sobre el asunto y, sobre todo, a manera de "una condena moral", ya no buscando justicia ante los tribunales eclesiásticos, sino remitiéndose al juicio de la posteridad:

Se preguntarán incesantemente por qué fueron abolidos los jesuitas; será siempre censurado el modo como se ejecutó la destrucción y no habrá quien, citando a nuestro siglo a su tribunal, no condene sin respeto alguno a los ministros que la sugirieron, a los principales que la pidieron, a los que a ella consintieron, y sobre todo al papa que la consumó, a los comisarios que la ejecutaron, al sacro colegio que no se opuso, a aquella chusma de religiosos y eclesiásticos fanáticos que la aplaudieron y al pueblo simple que se contentó de murmurar entre dientes. ${ }^{34}$

33. Francisco Xavier Clavijero, Sermón dirigido a sus hermanos exiliados en Bolonia en vísperas de la supresión de la Compañia de Jesús [febrero de 1773], Biblioteca Estense de Módena, ms., publicado en Alfonso Alfaro (coord.), Los jesuitas ante el despotismo ilustrado, Artes de México, núm. 92, 2008, sección Alebrije, p. 4.

34. Ibidem, pp. 46-47. También depositada en la Biblioteca Estense de Módena. Ambas se pueden consultar en la Biblioteca Virtual Miguel de Cervantes, con una presentación de Rinaldo Froldi. 
En medio de este juego de espejos, de amarguras y execraciones, ya veremos también cómo Clavijero, al final de su exilio, quiso morir invocando una de las imágenes "de su protector y abogado, cuya devoción procuró promover en cuantas partes estuvo", para asegurarse ad perpetuam su buena fama, emulando su mansedumbre o, al menos, la armonía consigo mismo.

Valga, antes de proseguir, hacer aquí un interludio guadalupano, ya que bien se sabe que la Virgen del Tepeyac era una devoción tan cara a nuestro autor y a la sensibilidad de sus compañeros de destierro. En su breve obra dedicada a promover el culto de la Virgen morena en Italia, publicada en Cesena en I782, Clavijero relataba el siguiente milagro, a propósito de una posesión diabólica sufrida por un viajero andaluz. Nótese que es un caso que había tenido su desenlace en el puerto de Veracruz (su patria chica), el cual, de manera por demás significativa, fue el único portento que incluyó como suma y epílogo de su obra (él, como sabemos, tan escéptico del maravillosismo del barroco) (fig. Ir). Pese a la alteración de una realidad física, se trataba de un prodigio creíble que ante su rigurosa crítica histórica no desmerecía divulgarse, como digno de todo crédito y admiración, pero en el que sin duda anidaba su patriotismo, la nostalgia y algo más:

A lo que se cree, no sólo las almas sino también los cuerpos fueron librados por la Virgen del yugo de Satanás. A ella se le atribuye que de doscientos cincuenta ańos para acá no se haya visto nunca energúmenos en este reino. Teniendo noticia de este hecho, un energúmeno en Andalucía, tras haber hecho cuanto se podía para librarse del demonio, se resolvió finalmente a viajar a México. Su esperanza fue premiada; porque al acercarse a las costas del país comenzó a sentirse mejor, y al pisar tierra en el puerto de Veracruz se sintió completamente liberado. Así pasó siete años, hasta que el amor a su tierra lo hizo volver a Espańa, pensando que la gracia recibida era estable y no restringida a lugar alguno. Mas apenas llegado a Cádiz se sintió de nuevo molestado por el espíritu del maligno; el cual, a la pregunta del exorcista, respondió que en México no podía molestar a aquel hombre porque la Virgen de Guadalupe se lo impedía. Finalmente se vio obligado a emprender de nuevo el viaje a América y llegando a Veracruz se vio otra vez libre de su mal y vivió en México hasta su muerte, para no separarse nunca de su Bienhechora. ${ }^{35}$

35. Francisco Xavier Clavijero, Breve noticia de la aparición de Nuestra Señora de Guadalupe en México, en Ernesto de la Torre y Ramiro Navarro, Documentos históricos guadalupanos, México, Fondo de Cultura Económica, I982, p. 595. 
I r. Filippo Vangelisti (dibujó) y Nicolo Mogalli (grabó), Milagro al energúmeno en

Veracruz, segunda mitad del siglo xviII, grabado sobre lámina, $20.5 \times 13.5 \mathrm{~cm}$. Foto: Eumelia Hernández. Colección Museo de la Basílica de Guadalupe.

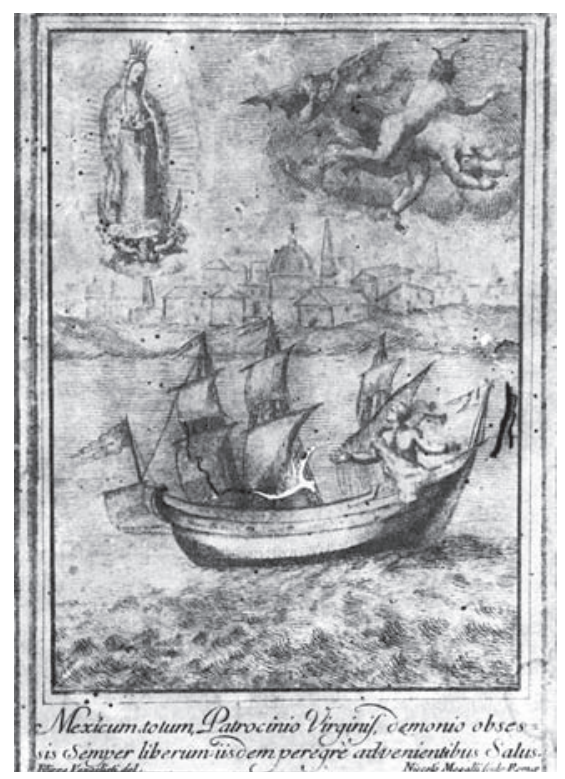

No puede dejar de pensarse, al leer esta historia de ida y vuelta, en la tradicional ojeriza habida entre criollos y gachupines; y, muy posiblemente, en la malicia del historiador jarocho para publicitarlo como una exempla social, destacando las ventajas de aquellos peninsulares que imitando a los criollos de sangre se tornaban en criollos de tierra, por el simple hecho de la adopción afectiva o por hacerse a los modos "de nuestras Indias". Es posible también que este lance, que tiene las trazas de un viejo tema literario, sea una réplica taimada de los criollos ante este tipo de cuartetas, que los difamaban por su derroche y su vida regalona:

Que si el mar fuera de atole

Y las olas de tortilla,

Navegaran los criollos

De Veracruz a Castilla.

Por el contrario, no se olvide que los criollos miraban en los inmigrantes españoles a un conjunto de advenedizos, de educación rupestre y carentes de buenos modos, que recién desembarcados en Veracruz se alistaban para acometer la depredación, la especulación y la usura. El tema de América como 
una madrastra ingrata para sus hijos y una madre nutricia y generosa para los extraños ya estaba en la pluma de un poeta criollo de I580, Francisco Terrazas, y la ojeriza entre ambos sectores se mantuvo hasta los últimos años del gobierno virreinal. La cuarteta del Negrito poeta es por demás elocuente tanto de la pervivencia de este estereotipo — del gachupín experto en el arte de medrar - como del mismo resentimiento que anidaba entre los grupos y sus representantes:

Dónde se ha visto en el mundo,

Lo que aquí estamos contemplando.

Los hijos propios gimiendo,

Y los extraños mamando. ${ }^{36}$

Pero lo más revelador de este exvoto guadalupano, más allá del pique localista, es que se resignifica en el contexto de su disputa con los historiadores deterministas europeos y "los filósofos", quienes tanto denigraban en sus escritos la naturaleza y las propiedades del suelo americano. En efecto, como aquí se ve, el autor magnifica su pertenencia a un territorio distinguido por la Virgen que goza de inmunidad contra el demonio. Lo cierto es que "el puerto de tablas", tal como se llamaba a Veracruz por su precaria arquitectura, era en realidad un destino sumamente maligno y fatal para todos aquellos europeos emigrantes que, en época de estiaje, desembarcaban allí sin el aparato inmune adecuado, o para hacer frente al tan temido "vómito negro" y a las picaduras de sus alimañas. El biógrafo Félix de Sebastián ya advertía el contrasentido entre el clima enrarecido de Veracruz y la fecundidad de sus talentos - como Clavijero, Alegre, Corro y Maneiro- gozando de una madre generosa, y así, empleando la indulgencia de la autocomplacencia criolla, sostenía: "La ciudad y puerto de Veracruz que con lo ardiente de su clima y feroz de su terreno parece infundía vivaces espíritus en sus naturales, habiendo sido madre fecunda de grandes ingenios y de ejemplares y doctos jesuitas".37

Una composición alegórica del pintor Francisco Antonio Vallejo es un excelente corolario a lo dicho hasta aquí (fig. I2). Es, bien vista, una declaración

36. Véase Arnulfo Herrera Curiel, La literatura novohispana del siglo XVI, tesis presentada para obtener el título de doctor en Letras, México, Universidad Nacional Autónoma de México-Facultad de Filosofía y Letras, 2005, pp. I03-133.

37. Trabulse, op. cit., p. 37. 
I2. Francisco Antonio Vallejo, Visión de san Juan en Patmos-Tenochtitlan, con san José y san Juan Nepomuceno, I77I, óleo sobre lámina de cobre, $84.5 \times 44.7 \mathrm{~cm}$. Colección Museo Soumaya. Fundación Carlos Slim, A.C. / Ciudad de México.

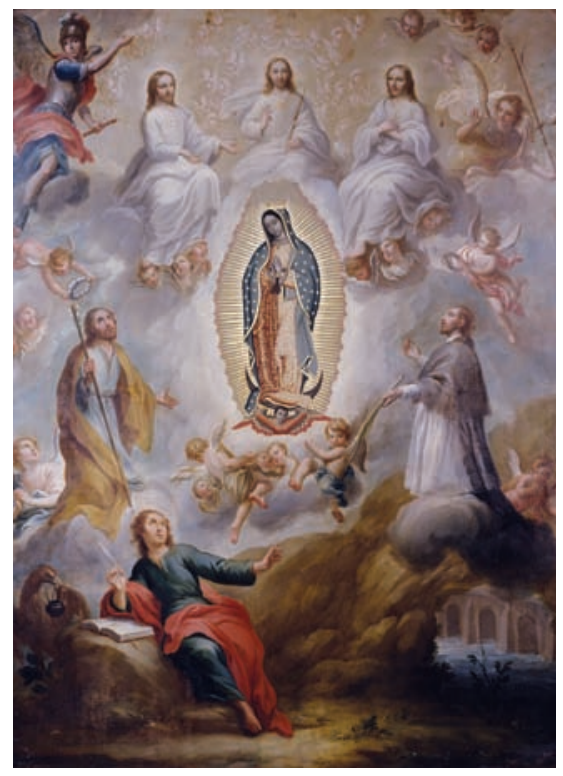

que honra al juramento de los tres patronos titulares y principales de la Nueva España: san José (patriarca de la Iglesia indiana y la conversión de los indios), la Virgen de Guadalupe (del reino, sus ciudades y villas) y san Juan Nepomuceno (de sus cabildos y más importantes corporaciones). Muestra, además, un escenario marítimo y celestial enmarcado en medio de la revelación que tuvo san Juan Evangelista en Patmos, según el capítulo I2 del Apocalipsis: contemplando la figura de la Mujer Águila encinta y huyendo hacia el desierto para escapar del acoso de la bestia infernal. Como se sabe, este pasaje lo interpretó desde mediados del siglo Xvir el teólogo criollo Miguel Sánchez, como una prefigura de las apariciones guadalupanas del Tepeyac en el valle de México. Por eso, aquí se mira "intervenido" el atributo principal de san Juan como escritor visionario, con pluma en mano: hay que notar que el águila no sólo es el tradicional símbolo que le corresponde en el tetramorfos (que además sostiene en el pico el tintero para que el evangelista moje la pluma), sino que se confunde deliberadamente con el ave fundacional de Tenochtitlán y, por eso mismo, se ha colocado a la vera de su tunal originario. ${ }^{38}$ Este imaginario criollo esta-

38. Jaime Cuadriello, "Visiones en Patmos Tenochtitlán”, en Visiones de Guadalupe, Artes de México, México, núm. 29, pp. I0-23. 
ba en consonancia con la decidida promoción que hacían los jesuitas de estos tres cultos y del papel protagónico que desempeñaron en las identidades locales. La obra de Vallejo sin duda se hace eco del "momento guadalupano", o cuando el papa Benedicto XIV declaró a la imagen del Tepeyac patrona principal de la Nueva España en 1754. Bien sabemos que esta gestión fue encabezada por los jesuitas en la figura del procurador Juan Francisco López, que viajó a Roma y se valió, para su buena fortuna, de las influencias en la corte del padre Francisco Rábago. Hay incluso una curiosa iconografía de "los tres juanes" (el Bautista, el Evangelista y el santo de Praga) reunidos como mártires y profetas, asociados no sólo por el nombre y su significativo papel revelado sino por su anclaje en los crecidos cultos locales y su reiterada liga con la visión guadalupana. ${ }^{39}$

Más aún, en su poema heroico el criollo José Agustín de Castro hermanaba a la Virgen del Tepeyac y al mártir del Moldavia en los accidentes del prodigio, o establecía una suerte de simulacro triunfal e imperecedero por las condiciones tan adversas en que sus figuras ganaron la gloria. No por azar ambas quedaban aromatizadas de flores y salpicadas de estrellas, pero sobre todo vinculadas por el poder de la elocuencia palpable en sus imágenes "mudas" o silentes:

El rocío de la aurora y el perfume

En Moldava, y sepulcro se anunciaron.

Y si al héroe difunto las estrellas

Fueron de sus victorias signos claros,

Ya quisiste también que en Guadalupe,

No faltasen estrellas al milagro:

Sírvante pues tus flores de laureles,

Cuando en mudos colores aclamamos,

A pesar del embate de los tiempos,

El triunfo del silencio más sagrado. ${ }^{40}$

Este imaginario, potenciado por la añoranza y la pesadumbre, se hizo presente en los años del exilio y es harto elocuente la promoción que los jesuitas hicieron de sus devociones preferidas, publicando opúsculos y poemas al santo

39. La obra se conserva en el Museo de la Catedral de León, Guanajuato, e incluye una escena de la confesión de la emperatriz.

40. Castro, op. cit., dedicatoria. 
bohemio o a la Virgen morena y entronizando sus imágenes en altares de las ciudades de los estados pontificios. Me parece muy sugerente, según la noticia e interpretación dada por el padre Maneiro, que el naufragio sufrido en el Mediterráneo por los jesuitas expulsos y su inexplicable salvación de ser ahogados produjeron en el afligido Clavijero una profunda huella, porque este percance desde sus adentros "había sido predicho en México", como un hecho que debía "atribuirse al patrocinio [jurado] a la Virgen de Guadalupe", que así no conocía fronteras y podía extender generosamente su manto, para beneficio y admiración de los forasteros, inclusive. En otras palabras, la Guadalupana reconocía los méritos de sus más fieles adalides y escuderos en la consecución de su patronato y así devolvía el favor apaciguando las furias marítimas o neutralizando las demoniacas.

En la moraleja de estos dos exvotos guadalupanos (uno relatado y otro vivido por Clavijero) quedaba claro que tanto para náufragos y energúmenos, como exiliados o repatriados, el santuario de la Virgen era una fortaleza inexpugnable y universal que aseguraba la conservación y la honra de todos aquellos que, vinieran de donde vinieran, se aceptaran como sus hijos. Con la publicación de Cesena, Clavijero cerraba en sus ańos postreros la lista de sus obras impresas, a modo de encomienda y tributo, aspirando a alcanzar la patria celestial: "Es interesantísimo el dato de que el último gran trabajo y fatigoso, de Clavijero sabio, haya sido por la Virgen de Guadalupe, a quien han amado y en cuyas apariciones han creído todos los jesuitas nacidos en México o adscritos a la provincia". ${ }^{4}$

De otras muchas maneras, las imágenes nepomucianas acompañaron la vida y los afanes del historiador veracruzano, ya en los colegios por los que transitó o bien bajo los mismos confesionarios, donde era usual colocar una estampa o labrar un relieve con la imagen del santo. En estos muebles, entre rocallas y roleos, exornado el copete del sitial, asomaba san Juan para avisar a los fieles sobre el buen arrepentimiento, la virtud del silencio y la prudente contención. Incluso, allí se podía ver una lengua roja y palpitante rodeada de ráfagas y destellos como una suerte de admonitorio “iDetente!”, enderezado contra la murmuración.

Por lo pronto, me interesa explayarme tan sólo en una imagen significativa bajo la cual, sin duda, nacía y florecía la vocación intelectual del sabio criollo, desde sus años de estudiante y más tarde como prefecto. Hay noticia, 
recogida en la crónica citadina de Juan de Viera, de tres grandes cuadros que engalanaban los muros del salón general del colegio de San Ildefonso o de la llamada "taza de oro" del plantel educativo (hoy museo que pertenece y enorgullece a la UNAM en cuyo "Generalito" el rector aún encabeza algunas de sus más graves ceremonias) (figs. I3 y I4). Se trataba de tres escenas hagiográficas a modo de presencias, que acompañaban desde el estrado las funciones o "academias" públicas de maestrillos y estudiantes, quienes allí desde lo alto se sometían a escrutinio de sus colegas de motu proprio. Al respecto, anota este cronista en 1778 , cuando el colegio ya era administrado por clérigos seculares luego de la expulsión:

En la cabecera de dicho General está una perspectiva al óleo, que representa un prodigioso tabernáculo en cuyo centro está san Luis Gonzaga y en el otro frente está el martirio de san Juan Nepomuceno, y de otro santo, san Josafat, que también padeció martirio arrojado a un río. ${ }^{42}$

En palabras de José Bernardo Couto, este pendant de los mártires muertos en la ribera fluvial era "no muy feliz a la verdad" y, en cambio, la pintura central gonzaguina firmada por José de Ibarra en 1740 despertó todo su entusiasmo por parecerle la "más importante obra del artista en México" y por la "mucha ventaja" del partido compositivo que sacó de sus modelos. ${ }^{43}$

Si el Gonzaga era una imagen de asunto moral (paradigma de castidad y entrega para los estudiantes "en la guarda de la pureza"), los martirios sin duda guardaban connotaciones políticas. Aquella dupla de Nepomuceno y Josafat componía en verdad un argumento ejemplar y por demás pertinente: ambos fueron dignidades del clero secular en la Europa del Este, martirizados en defensa de la institucionalidad de la Iglesia ante el despotismo de los príncipes. En sus figuras había un eco de los afanes de la Compañía por colocarse como imprescindibles agentes entre los intereses del poder y la educación de la clase dirigente (no obstante pagaran con su vida el celo a su ministerio). En realidad, en este pendant anidaba un mensaje nada inocente para presidir las ceremonias y los certámenes escolares, que Clavijero encabezó allí en sus intentos de reno-

42. Juan de Viera, Breve y compendiosa narración de la ciudad de México, México, Instituto Mora, I992, p. 73.

43. José Bernardo Couto, Diálogo sobre la historia de la pintura en México, Juana Gutiérrez Haces (est. introd.), José Rogelio Ruiz Gomar (notas), México, Consejo Nacional para la Cultura y las Artes, I995, p. 106. 
vación educativa. Aunque las pinturas fueron desmanteladas por el positivismo de Gabino Barreda al triunfo de la República (otra manera de intolerancia ante un pasado irreconciliable), ahora puedo decir, con un buen grado de certeza, que afortunadamente ha quedado un testimonio visual de aquello que la iconoclasia liberal se encargó de borrar de la memoria. Se trata de las dos laminitas de cobre que hoy se custodian en la oficina del director del Instituto de Investigaciones Estéticas de la Universidad Nacional Autónoma de México, que no sólo son obras factiblemente atribuibles al pincel de José de Ibarra, sino que constituyen la primera idea o la traducción, como una suerte de bozzetini, de aquellas enormes pinturas murales ahora desaparecidas. Más allá de que coincida la descripción de Viera con las imágenes de estos santos ahogados y sufriendo el escarnio público, es un hecho incontestable la participación de Ibarra en este proyecto "total", de prestigio y novedad, que le mereció el aplauso público y luego el trato como pintor decano de su gremio. Un reconocimiento venido justo en el cenit de su carrera, que se pone de manifiesto en la misma calidad y exquisitez de estas dos laminitas mixtilíneas, hasta ahora sin paternidad. Bien vistas, están pensadas como composiciones de mayor aliento: la amplitud y profundidad del paisaje y las figuras centrales en primer plano revelan que se trata de "invenciones" para su traslado a un formato mayor y, no por acaso, con un punto de vista di sotto in su.

Lo dicho también confirma la opinión de Paula Mues en el sentido de que Ibarra, como partícipe y cabeza de las academias de pintura desde la primera mitad del siglo XVIII, gustaba de usar bocetos o tareas previas para luego satisfacer las necesidades de su poderosa clientela. Esta autora lo prueba mediante el hallazgo del único dibujo preparatorio o de invención de Ibarra, de hecho hasta ahora el único conocido en la historia de la pintura virreinal, publicado no hace mucho merced a sus pesquisas. ${ }^{44}$ Aquí no puede dejar de verse la sorprendente similitud entre ese diseño hecho por el mismo Ibarra para ilustrar el Escudo de armas de México de Cayetano Cabrera y Quintero de 1746 y el mismo tratamiento de gente y figuras que se mira en la lontananza de la escena nepomuciana, con una multitud azorada y dolida por el martirio, contenida ante los hitos arquitectónicos y las murallas de las imaginarias ciudades de México y Praga (por cierto, el libro de Cabrera fue censurado y recogido por la Inquisición también por agraviar a cierto poderoso). Por si quedara duda de su em-

44. Paula Mues Orts, El arte maestra, traducción novohispana de un tratado pictórico italiano, México, Museo de la Basílica de Guadalupe, 2006, pp. 74-76. 


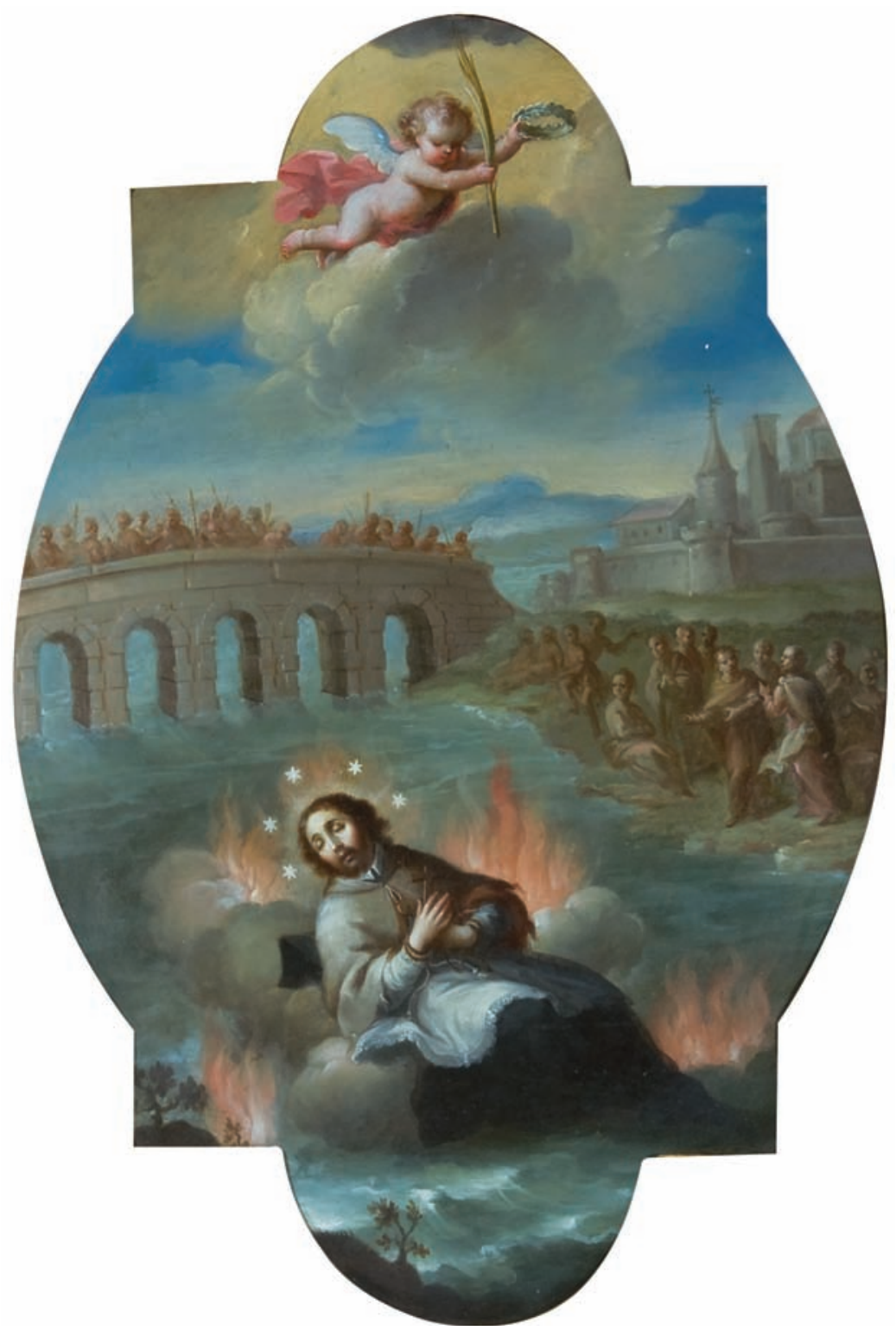

I3. José de Ibarra (atribución), El cuerpo de san Juan Nepomuceno flota sobre el río Moldavia, ca. $\mathrm{I} 74 \mathrm{O}$, óleo sobre lámina de cobre, $4 \mathrm{I} . \mathrm{I} \times 28 \mathrm{~cm}$. Foto: Eumelia Hernández, 20I I. Colección Instituto de Investigaciones Estéticas, UNAM. 


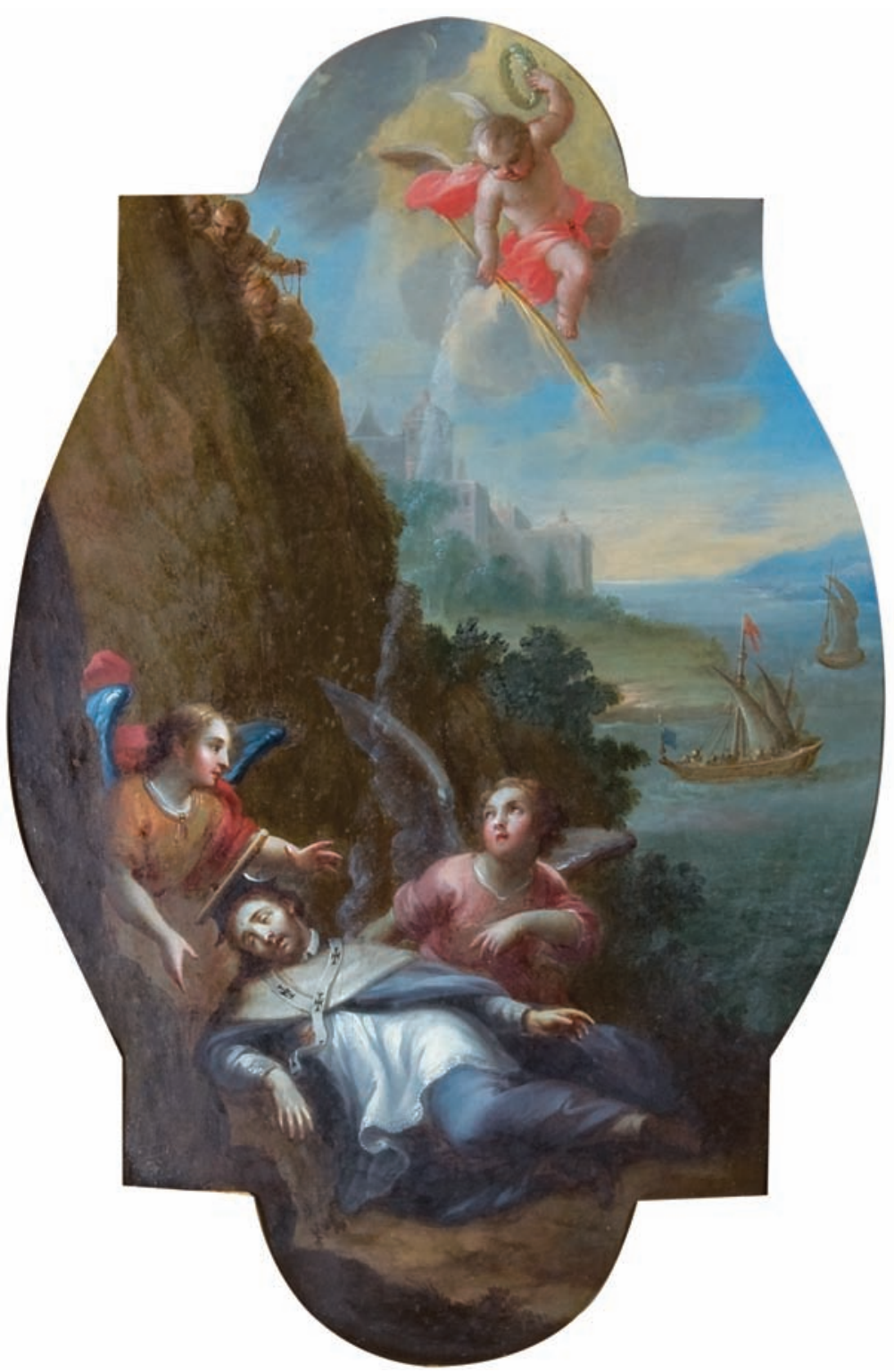

I4. José de Ibarra (atribución), El cuerpo de san Josafat de Polotsky en la ribera del rio Duna, ca. $\mathrm{I740}$, óleo sobre lámina de cobre, $40.5 \times 28 \mathrm{~cm}$. Fotografía: Eumelia Hernández, 20I I. Colección Instituto de Investigaciones Estéticas, UNAM. 
plazamiento y atribución, nótese que el lobulado de sus marcos se corresponde en todo a las grandes ventanas mixtilíneas del salón general de San Ildefonso; por tanto, es probable que este pendant de enormes cuadros estuviera tapiando un claro de luz o que, colocado al pie del salón, se replicara con el mismo ritmo y formato de los cornisamientos y ventanales en los paños interiores.

Nótese además que ambos santos reciben desde las alturas la palma y la corona del martirio por sus méritos e integridad, pero, si los ángeles custodian el cuerpo de san Josafat in sommno pacis o en su puerto de quietud, el cuerpo de Nepomuceno flota milagrosa y triunfantemente sobre las aguas del Moldavia, entre las llamas y las estrellas que guardaban su buena fama para memoria de la posteridad. Por lo demás, ambos cultos llegaron a ser, luego de la expulsión de Carlos III, un mecanismo de protesta y recordación. Tanto así que las imágenes de san Josafat, que padeció las intrigas por reconciliar a los cismáticos, fueron prohibidas por la Inquisición (al conocerse que en su culto se cuestionaba la pragmática real de 1767) y el culto de Nepomuceno que, como ya hemos dicho, significaba una alternativa para manifestar la nostalgia local por los jesuitas castigados con el exilio. En suma, bajo estos cuadros murales se escucharon las primeras voces de la renovación filosófica de Clavijero y sus discípulos, afanados en traducir y actualizarse no sólo acorde con las novedades del racionalismo ilustrado sino con una identidad edificada desde la memoria y el patriotismo local; desde luego, contestando a la Real y Pontificia Universidad que como nunca perdía terreno y liderazgo aferrada a su peripatética visión del conocimiento.

Sin embargo, el paso de Clavijero por San Ildefonso fue otra dura prueba para templar su carácter, ya que resintió la oposición cuando intentó por primera vez renovar los sistemas de estudio:

Por entonces fue nombrado Clavijero prefecto de los alumnos del Colegio de San Ildefonso de México. Ya antes hemos dicho la enorme importancia que llevaba consigo este cargo, porque allí se formaban quienes habían de ser la clase dirigente del país. Hubiera querido modelar las mentes y educar a las personas de sus alumnos, conforme a sus ideas tan trabajosamente elaboradas. Pero advirtió ser arduo y peligroso desterrar, apenas llegado, las corruptelas que se habían metido en los colegios de entonces, y decidió callar y no introducir absolutamente ninguna novedad. Acallaba las protestas de su conciencia, con repetirse que él no era sino las manos del rector; pero no dejaba de ser un tormento el tener que estar procediendo contra 
lo que él veía dictado por los sanos principios, y estar exigiendo a los muchachos lo que veía ser un absurdo.

Al cabo, luego de sincerarse con el rector del colegio y de ganar su reconocimiento por el dominio de sí, este último le predijo la razón que asistía a sus afanes intelectuales: "Estos planes suyos, hermano Clavijero, tenga por cierto que se realizarán a tiempo". 45

No fue la de Clavijero una devoción pasajera u oportunista y sin duda el duro trance del destierro aumentó el fervor o más bien fue el detonante, como en otros tantos jesuitas, de una identificación o autoproyección en la mismísima figura de este mártir del celo sacerdotal: sobre todo cuando cargó a cuestas con los efectos de la traducción de su Storia antica di Messico, vetada para el público español por el Consejo de Indias y los propios jesuitas españoles que sentían agraviada su hispanidad. Se dijo entonces "que para reparar el escándalo" no se conozca ni se cite ni se lea, decía el dictamen, o más bien la desaforada censura de Diosdado Caballero avalada por la tibieza del ministro de Indias José de Gálvez. ${ }^{46}$ En la prensa y los corrillos no le faltaron las descalificaciones de otros académicos sobre minucias y aparentes faltas, en realidad pretextos ideológicos para no mirar la colosal empresa de su obra y el desmentido que hacía de los historiadores sobre América llegados de última hora: que si había plagiado a Torquemada, que si adolecía de ideas propias, que si los méritos de Cortés y de los espańoles quedaban rebajados; sobre todo, que las razones teológicas de la Conquista (y por ende el Real Patronato) habían quedado despojadas de su significado trascendente. Ya que por primera vez en la historiografía colonial se había exorcizado el pasado antiguo de los mexicanos y así el diablo, que enseñoreaba toda su cultura y literatura, quedaba literalmente cojuelo. 47

Hay que advertir que su obra cumbre estuvo dedicada, de manera por demás reveladora, a la Universidad de México y a sus ingenios, cuyo patrón más celebrado era en ese entonces el Nepomuceno mártir (figs. I5a y b). De una forma velada, sin nombrarlo pero describiendo sus virtudes, el autor hacía un sentido reconocimiento al señor rector, otrora su antiguo maestro, el bibliófilo

45. Maneiro, op. cit., pp. 448-449.

46. Elías Trabulse, "Un airado mentís a Clavijero", Historia Mexicana, núm. 97, I975, pp. I-40; Charles E. Ronan, Francisco Javier Clavijero, figura de la ilustración mexicana, su vida y obras, Guadalajara, Universidad Jesuita de Guadalajara, 1993, p. 225.

47. David Brading, Orbe indiano, México, Fondo de Cultura Económica, I991, pp. 456-500. 

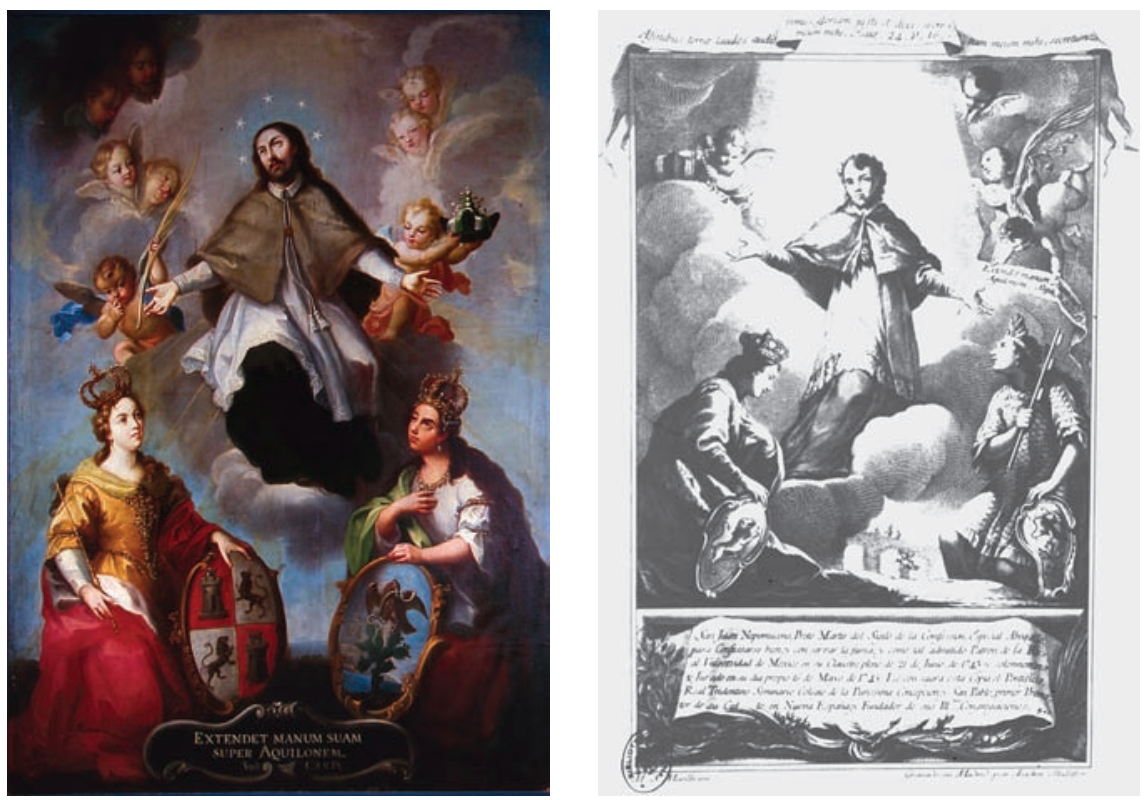

I5 a) Anónimo novohispano, Alegoría de la jura de san Juan Nepomuceno como patrono de la Universidad de México, y la personificación de los reinos de España y Nueva España, I745, óleo sobre tela, $269 \times$ I9I cm, Museo Nacional de Historia. Conaculta-INAH-MÉx. "Reproducción autorizada por el Instituto Nacional de Antropología e Historia”; b) Mariano Salvador Maella (dibujó) y Joaquín Ballester (grabó), Alegoría de la jura de san Juan Nepomuceno como patrono de la Universidad de México, y la personificación de los reinos de España y Nueva España.

Biblioteca de Estampas, Gabinete de Estampas, Madrid. Tomadas de La pintura emblemática en la Nueva España, México, Museo Nacional de Arte, 2004, pp. I05 y 385.

y erudito Luis Antonio Torres Tunón. Esta muda dedicatoria era en realidad un exhorto abierto a todos los estudiosos del reino para que aquella máxima casa de estudios, como matriarca generosa y memoriosa, asegurara las libertades intelectuales. Todo mediante el estudio y la conservación de las antigüedades allí depositadas, para que se cultivase entre los jóvenes la ciencia de la historia como un asunto primordial de "amor a la patria". En lo mejor de sus afanes, la biblioteca de la universidad (resguardo del Museo de Lorenzo Boturini) estaba llamada a ser el depósito de la conciencia nacional, y sus tesoros y manuscritos, abiertos a la consulta pública, deberían guiar los pasos de quienes estuviesen dispuestos a seguir con fidelidad y empeño aquellas "dos santas 
leyes de la historia: no atreverse a decir mentira, ni temer a decir la verdad". Pese a las "tribulaciones" y "calamidades" que lo habían limitado en su investigación, creía "no haberlas quebrantado", y así el autor era consecuente con su denodado afán ulterior: que a su patria —y a sus hombres— nunca más se le difamase en el extranjero mediante la falsa pluma de los filósofos de gabinete y salón. Justo a quienes Clavijero siempre opuso su crítica y mostró, con la evidencia y solvencia de una erudición formada in situ, toda la fuerza de sus renovadoras, cuan incómodas, afirmaciones. Por algo dijo desde las primeras líneas que en el seno de ese "respetable" claustro universitario de México no buscaba "protector que lo defienda, sino conductor que lo guíe y maestro que lo ilumine", y en el prólogo insistió en que por medio de sus "diligencias por averiguar la verdad" quiso contradecir los "hechos inventados por el capricho, [tal] como veo lo hacen no pocos autores de nuestro ponderado siglo". ${ }^{8}$

Los ataques a su honra no sólo habían sido una cuestión intelectual sino eminentemente moral, o como bien dijo Maneiro desde los tiempos poblanos en que se intentó censurar sus Memorias edificantes: en la defensa de la verdad desnuda iba de por medio su pública honradez científica. Al paso de los años, pues, el mismo credo confesaba Clavijero en el prólogo de la Storia antica, o más bien lo refrendaba como una declaración de principios, pero ahora suscrita en Bolonia en I780: "Enemigo [como soy] de todo engaño, mentira y afectación, me parece que la verdad es tanto más hermosa cuanto está más desnuda". ${ }^{49} \mathrm{Y}$ esta voluntad por escudriñar el pasado en sus causas más profundas, para obtener un criterio de verdad y compartirlo entre los suyos, le había sido inculcada desde niño, según Maneiro: "Un simple indicio lo llevaba a investigar más profundamente una cosa, y compulsaba los nuevos conocimientos con los antiguos, y los dudosos con los ya ciertos, de modo que unos iluminaran a otros, hasta obtener la posesión completa de la noción del objeto tras que andaba". 50

En el espejo de la vida de san Juan Nepomuceno otros tantos jesuitas se miraron, igualmente víctimas del despotismo real, y en ese trasunto figural, en lugar de hablar mal de la Corona española y condenar sus decisiones de estado, a la postre se consagraron silenciosamente a sus afanes intelectuales. Incluso en pos de mantener la honra de su provincia mexicana, algunos jesuitas

48. Francisco Xavier Clavijero, Historia antigua de México, Mariano Cuevas, S.J. (ed. y pról.), México, Porrúa, I964, pp. XVII-XIX.

49. Ibidem, p. XXII.

50. Maneiro, op. cit., p. 446. 


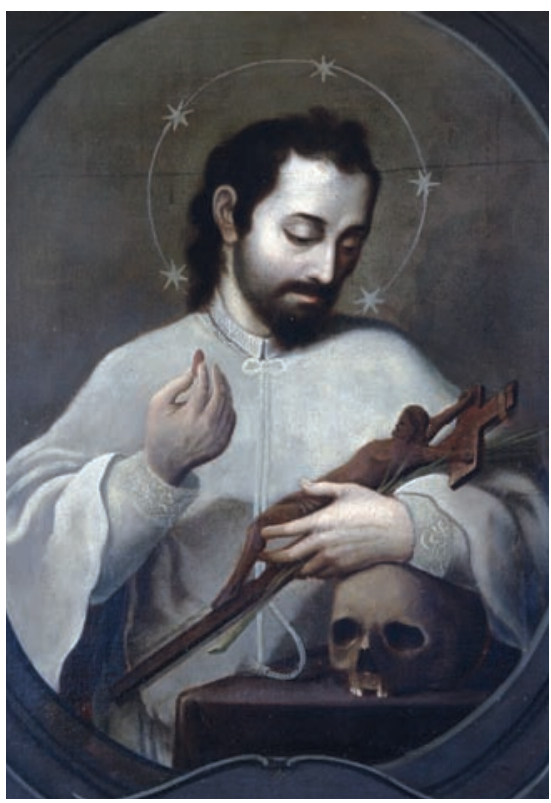

I6. Francisco Antonio Vallejo (atribución), San Juan Nepomuceno, segunda mitad del siglo XviII, óleo sobre tela. Colección Museo Soumaya. Fundación Carlos Slim, A.C. / Ciudad de México.

mexicanos e hispanoamericanos, como Valdivieso, Viescas y Escobedo, peregrinaron hasta Praga para venerar in situ los restos del santo y allí imploraron la entereza necesaria para sobrellevar la supresión de la Compañía ese mismo ańo de $1773 .{ }^{5 \mathrm{II}}$ Una extinción dictada por un breve pontificio emitido a gusto y pedido de los reyes absolutistas, como hemos visto, pero ahora configurados en tribunal de estado o comité ad hoc para abolir a los contrarios.

Tanta fue la fortaleza sanjuanista del historiador veracruzano que su compañero Félix de Sebastián hizo el siguiente retrato de sus últimos instantes, cuando fallecía en Bolonia la tarde del 2 de abril de 1787 :

Ya en su lecho de muerte Clavijero recurría con gran fervor a la Santísima Virgen a quien tiernamente veneraba; a nuestro padre san Ignacio de quien se honraba ser hijo, al santo de su nombre san Francisco Xavier que amó entrańablemente; y a su protector y abogado san Juan Nepomuceno, cuya devoción procuró promover en cuantas partes estuvo (fig. I6). ${ }^{2}$

51. Stepanek, op. cit., p. 70.

52. Trabulse, Clavigero, op. cit., p. 5 I. 
A renglón seguido, el retrato moral que allí mismo se leía dejaba en claro cuán lejos estaban las virtudes de Clavijero de aquellas miserias y truculencias de la vida, que tradicionalmente castigaba la impoluta lengua del mártir de Praga. Como buen seguidor de la filosofía moral, todos sus talentos intelectuales estaban subordinados a la virtud de quien hace suyos los significados del hablar y escribir: "Su carácter definitivo fue siempre la humildad, sin reconocérsele engreimiento en cosa alguna. Su boca era toda dulzura para todos, su proceder amable, sus entrañas tiernas y sus modos y maneras dignas de aquella alma que lo animaba". O dicho en cristiano: En boca cerrada, no entran moscas. \&

* Artículo recibido el I7 de mayo de 20 I I; aprobado el 26 de septiembre de 20 I I. 